\title{
Integrated crop managements through optimal planting date and nitrogen fertilizer levels in wheat - sugar beet association on competitive relationships and yield advantages
}

\author{
Kamel S. A. Badr **; Mohamed I. Salwau*; Sadiek A. S. Mehasen*; Kamel A. El - Doby** \\ *Fac.of Agric Moshtohor, Benha Univ. *** Field Crop Res., Agric. Res. Center \\ Corresponding author: Kimobadr332@yahoo.com
}

\begin{abstract}
Two field experiments were carried out in Sers EI - Lian Research Station (A.R.C) Menofyia Governorate, Egypt in 2013/2014 and 2014/2015 seasons to investigate the effect of three sowing dates of wheat with sugar beet, four intercropping patterns and three nitrogen fertilizer levels on competitive relationships, yield advantage and cereal units of wheat with sugar beet. A split - split plot design with three replications was used.

The most import results can be summarized as follows:

The highest value of land equivalent ratio (LER) 1.36 was obtained when sowing wheat with sugar beet at the first irrigation and intercropping patterns (100\% sugar beet $+33.3 \%$ wheat) in ridges at $120 \mathrm{Kg} \mathrm{N} / \mathrm{fed}(\mathrm{D} 2 \times \mathrm{S} 3 \times$ N3) in combined analysis of two seasons. The best results for relative crowding coefficient (K) was (15.12) achieved with wheat planting at second irrigation of sugar beet with intercropping pattern $(100 \%+25 \%)$ sugar beet/wheat in ridges $(60 \mathrm{~cm}$ wide) and fertilized by $100 \mathrm{Kg} \mathrm{N} / \mathrm{fed}(\mathrm{D} 3 \times \mathrm{S} 1 \times \mathrm{N} 2)$ in combined analysis of the two seasons. Combined data over two seasons of aggressivity (A) revealed that wheat was the dominant component and sugar beet was dominated in combined analysis. Aggressivity values were increased with wheat planting at first irrigation of sugar beet under combination between different intercropping pattern and nitrogen fertilizer rates the highest values (0.62) was obtained at first irrigation of sugar beet with intercropping pattern (100\% sugar beet $+25 \%$ wheat $)$ on beds and 80 or $100 \mathrm{Kg} \mathrm{N} /$ fed $(\mathrm{D} 2 \times \mathrm{S} 2 \times \mathrm{N} 1$ or N2). Whereas, the lowest values $(0.17)$ of $\mathrm{A}$ were showed with the second irrigation of sugar beet with two factors (D3 $\times$ S3 $\times$ N3). The highest values of cereal units (113.80)/fed was obtained when wheat just before the first irrigation of sugar beet and intercropping pattern $(100 \%$ sugar beet $+33.3 \%$ wheat $)$ in ridges and $120 \mathrm{Kg} \mathrm{N} / \mathrm{fed}(\mathrm{D} 2 \times \mathrm{S} 3 \times \mathrm{N} 3)$. in combined analysis of two seasons. While the lowest one (97.76) cereal unit/fed was obtained with sugar beet at the same irrigation with intercropping pattern $(100 \%$ sugar beet $+33.3 \%$ wheat $)$ on beds and $80 \mathrm{Kg} \mathrm{N} / \mathrm{fed}(\mathrm{D} 1 \times \mathrm{S} 4 \times \mathrm{N} 1)$.
\end{abstract}

Keyword: wheat - sugar beet - intercropping - competitive relationships - yield advantageous - cereal units

\section{Introduction}

Sugar beet (beta vulgaris L.) is an important crop not only in Egypt, but also all over the world as a source of sugar industry. In Egypt, it is the second sugar crop after sugar cane. Sugar beet successfully grows in the newly reclaimed soils by about 104069 and 131308 fed and about $400293^{*}$ and 423633 fed in old lands in 2013/2014 and 2014/2015 seasons, respectively. Egyptian government imported 1129692 ton of sugar in 2014 to meet the needs of the rapid increase of population. ${ }^{*}$ It gives higher yield and growth period is about $1 / 2$ of sugar cane in season (6-7 months) and it has lower water $1 / 4$ requirements of sugar cane. Wheat (T. aestivum $\mathbf{L}$.) is one of the most cereal crops in the world as well as in Egypt. The increasing wheat production can achieved by increasing the wheat area (more than 3 million/fed), higher varieties and improving cultural practices.

As an attempt to narrow the gap in sugar and wheat by intercropping wheat with sugar beet successfully, without any change in sugar beet density.

Intercropping wheat with sugar beet ridges or beds is one of the most important practices as a means of maximizing productivity and allow full utilization of the environmental resources with minimum competition, especially for light, water and nitrogen fertilizer levels. In this respect (Willey 1979) revealed that a major cause of yield advantage intercropping is the better use of grow resources. Metwally et al. (1997) reported that intercropping is one of the most practices as away to increase the productivity per unit area especially in new reclaimed land. Toaima (2006) intercropped 4 lines of wheat on back beds $(120 \mathrm{~cm})$ of fodder beet under different NPK fertilization levels, found that the highest LER was (1.42) and $\mathrm{K}$ was (7.90) at the highest level of N.P.K (120, 50 and 72 $\mathrm{Kg} / \mathrm{fed}$ ). Sugar beet was dominant and wheat was dominated in both seasons. Attia et al. (2007) revealed that LER was (1.30 and 1.33) and $\mathrm{K}$ was (4.43 and 4.97) achieved with three rows of wheat intercropped with sugar beet in the first and second seasons respectively. Abd EL - Gwad et al. 2008) indicated that intercropping $50 \%$ of wheat with fodder beet increased land usage and proved advantageous by $1.21,1.07,1.15$ and $1.22 \%$ for $70,90,110$ and $130 \mathrm{Kg}$ $\mathrm{N} /$ fed, respectively. Ibrahim et al. (2008) showed that

The highest values of LER (1.33 and 1.39) and $\mathrm{RCC}(\mathrm{K})$ (6.79 and 8.6) were recorded at 2 rows of wheat with $100 \%$ sugar beet. Aggressiviety, sugar beet was dominant and wheat was dominated. Abd 
EL - Zaher et al. (2009) observed that the highest values of LER (1.82 and 1.80), RCC (107.60) and aggressivity values of barley was dominated when intercropping system (100\% sugar beet $+67 \%$ barley) (4 rows) in the first and second seasons, respectively. Abou - Elela(2012) mentioned out that the highest values of LER was (1.31 and 1.25), RCC was (12.99 and 5.36) when intercropping $25 \%$ wheat on the top of the second bed of sugar beet in both seasons, respectively. Badr (2013) found that the highest values of LER were (1.48 and 1.43), cereal units (97.54 and 105.95 fed) and $\mathrm{K}$ (10.98 and 9.71) were obtained with $(100 \%$ sugar beet $+50 \%$ wheat $)$ and fertilized with 120 or $140 \mathrm{Kg} \mathrm{N} / \mathrm{fed}$ in both seasons. Whereas the maximum values of cereal units/fed (102.68) recorded at $100 \%$ sugar beet $+50 \%$ wheat) with $140 \mathrm{Kg} \mathrm{N} /$ fed in the first season and (111.93) cereal units/fed in the second season at (100\% sugar beet $+25 \%$ wheat) under $120 \mathrm{Kg} \mathrm{N} / \mathrm{fed}$. Aggressivity values of wheat were positive (dominant) and sugar beet was negative (dominated) under all intercropping patterns. Dina EL - sherief (2013) showed that intercropping sugar beet and wheat increased land usage by $37,35,31$ and $33 \%$ over monoculture of both crops at wheat hill spacing 20, 40, 60 and $80 \mathrm{~cm}$ as average of two seasons. The greatest values of $\mathrm{K}$ (4.72) when intercropping wheat with sugar beet in hills $20 \mathrm{~cm}$ in the first season and $\mathrm{K}(39.73)$ recorded when intercropping wheat and sugar beet at $80 \mathrm{~cm}$ between hills in the second season. Hala Shehata (2015) found that the maximum values of LER were $(1.23+1.25)$, RCC (3.25 and 4.47) and cereal units (87.12 and 92.61/fed) achieved with intercropping pattern $(100 \%$ sugar beet $+37.5 \%$ wheat $)$ in the first and second seasons, respectively. However aggressivity values of sugar beet were positive (dominant) at 3 intercropping pattern and wheat was positive (dominant) at one in the first season and opposite trend in the second season.

The aim of this research is to investigate the effect of sowing date of wheat with sugar beet, intercropping pattern under nitrogen fertilizer levels of wheat with sugar beet on competitive relationships, yield advantages and cereal units/fed.

\section{Materials and Methods}

Two field experiments were conducted at Sers El - Lian Agriculture Research Station, (ARC), Menofyia governorate, during two the successive seasons 2013/2014 and 2014/2015 to study the effect of three sowing dates of wheat (T. aestivum L.) CV. Gemmeiza 11 with sugar beet (Beta Vulgaris L.) CV. Mezzano, four intercropping patterns and three nitrogen fertilizer levels on competitive relationships, yield advantages and cereal units/fed of sugar beet and wheat crops.

The soil type clay loam in the first and second seasons, respectively. The mechanical and chemical analysis of the experimental sites are recorded in Table (1).

The average of climatic factors during the growth seasons in 2013/2014 and 2014/2015 are presented in table (2). The preceding summer crop was maize in both seasons. A split - split plot design with three replication was used. Each experiment consists of 36 treatments which were the combination of three sowing dates of wheat with sugar beet, allocated to the main plots, four intercropping patterns arranged in the sub plots and three nitrogen fertilizer levels were assigned at random in the Sub - Sub plots; in addition two pure stand of sugar beet and wheat.

Table 1. Some physical and chemical properties of the experimental soil in 2013/2014 and 2014/2015 seasons.

\begin{tabular}{|c|c|c|}
\hline Seasons & 2013/2014 & $2014 / 2015$ \\
\hline \multicolumn{3}{|l|}{ a. Mechanical analysis } \\
\hline & 1.27 & 1.59 \\
\hline \multicolumn{3}{|l|}{ coarse sand\% } \\
\hline fine sand \% & 27.12 & 32.12 \\
\hline silt \% & 30.90 & 27.89 \\
\hline clay $\%$ & 40.71 & 38.40 \\
\hline soil texture & clay loam & clay loam \\
\hline \multicolumn{3}{|l|}{ b. chemical analysis } \\
\hline PH & 7.80 & 7.48 \\
\hline \multicolumn{3}{|l|}{ soluble cations $(\mathrm{mg} / \mathrm{L})$} \\
\hline Ca++ & 5.80 & 2.10 \\
\hline Mg++ & 2.30 & 1.20 \\
\hline $\mathrm{Na}+$ & 6.25 & 3.70 \\
\hline $\mathbf{K}+$ & 8.81 & 7.25 \\
\hline \multicolumn{3}{|l|}{ soluble anions(mg/L) } \\
\hline Co3-- & - & - \\
\hline Hco3- & 3.02 & 3.20 \\
\hline CL- & 4.91 & 3.80 \\
\hline So4-- & 3.94 & 3.25 \\
\hline N PPm & 40.00 & 51.00 \\
\hline P ppm & 21.00 & 67.00 \\
\hline
\end{tabular}


K ppm

348.00

397.90

Table 2. Meteorlogical records of Minofyia governorate at monthly period from Nov. to May in 2013/2014 and 2014/2015 seasons.

\begin{tabular}{|c|c|c|c|c|c|c|c|c|c|c|}
\hline \multirow[t]{2}{*}{ seasons } & \multicolumn{5}{|c|}{$2013 / 2014$} & \multicolumn{5}{|c|}{$2014 / 2015$} \\
\hline & $\mathrm{T}$ & & & rain & & & & & rain & \\
\hline Months & $\operatorname{Max}$ & T Min & RH\% & $(\mathrm{mm})$ & SRAD & T Max & $\mathrm{T}$ Min & RH\% & $(\mathrm{mm})$ & SRAD \\
\hline Oct. & 30.18 & 15.58 & 45.2 & 2.5 & 15.1 & 30.65 & 17.05 & 43.9 & 0.1 & 18.23 \\
\hline Nov. & 27.12 & 14.62 & 57.7 & 14.1 & 13.08 & 25.38 & 13.33 & 55.5 & 12.9 & 12.93 \\
\hline Dec. & 20.1 & 8.48 & 57.8 & 22.4 & 10.93 & 22.74 & 10.31 & 53.7 & 34.7 & 11.2 \\
\hline Jan. & 20.88 & 8.5 & 57.6 & 38.3 & 12.51 & 18.88 & 7.14 & 55.8 & 11.9 & 11.71 \\
\hline Feb. & 22.46 & 8.23 & 49 & 12.2 & 15.38 & 20.31 & 7.73 & 46.2 & 2.3 & 13.62 \\
\hline Mar. & 25.59 & 10.41 & 45.8 & 1.7 & 19.37 & 25.45 & 10.74 & 37.3 & 4.1 & 15.41 \\
\hline Apr. & 30.67 & 13.56 & 30.1 & 5.2 & 23.16 & 28.51 & 11.68 & 38.9 & 5 & 23.03 \\
\hline May. & 33.76 & 17.63 & 30.7 & 1.8 & 25.56 & 34.07 & 16.78 & 32.1 & 0.1 & 26.65 \\
\hline Total & & & & 98.2 & & & & & 71.1 & \\
\hline
\end{tabular}

(T MAX, $\mathrm{C}^{0}$ ) maximum temperature, $\left(\mathrm{T}\right.$ MIN, $\left.\mathrm{C}^{0}\right)$ minimum temperature, relative humidity (RH\%), rain fall (Rain mm), Solar radiation( $\mathrm{SRAD}, \mathrm{Mi} / \mathrm{m}^{2} /$ day).

Agriculture Research Center.

Soil, Water \& Environment Research Institute

Department of Water Requirements and Field Irrigation.

The treatments studied were as follows:

\section{A. Sowing dates of wheat:}

$\mathrm{D}_{1}$. Sowing wheat and sugar beet at the same time.

$\mathrm{D}_{2}$. Sowing wheat on the $1^{\text {st }}$ irrigation, of sugar beet.

$\mathrm{D}_{3}$. Sowing wheat on the $2^{\text {nd }}$ irrigation, of sugar beet.

\section{B. intercropping patterns:}

$S_{1}$. (100\% sugar beet $+25 \%$ wheat of pure stand) sugar beet was planted on one side of the ridge $(60 \mathrm{~cm}$ width), $20 \mathrm{~cm}$ apart between hills and thinned one plant/hill and wheat was sown on the other side of the second ridge of sugar beet in hills.

$\mathrm{S}_{2}$. (100\% sugar beet $+25 \%$ wheat of pure stand) sugar beet was planted on both sides of the bed (120 $\mathrm{cm}$ width), $20 \mathrm{~cm}$ apart between hills and thinned one plant/hill and wheat was planted on the top of all beds in hills.

$\mathrm{S}_{3}$. (100\% sugar beet $+33.3 \%$ wheat of pure stand $)$ sugar beet was planted on one side of the ridge $(60 \mathrm{~cm}$ width), $20 \mathrm{~cm}$ apart between hills and thinned one plant/hill and wheat was sown on the other side of the second ridge of sugar beet in hills.

$\mathrm{S}_{4}$. (100\% sugar beet $+33.3 \%$ wheat of pure stand) sugar beet was planted on both sides of the bed (120 $\mathrm{cm}$ width), $20 \mathrm{~cm}$ apart between hills and thinned one plant/hill and wheat was planted on the top of all beds in hills.
In addition to (100\% sugar beet pure stand of sugar beet was planted one side of the ridges $(60 \mathrm{~cm}$ width $)$ spaced at $20 \mathrm{~cm}$ apart between hills to give 35000 plant/fed. and pure stand of wheat $100 \%$ Planted on broadcasting $60 \mathrm{~kg}$ seed/fed.

\section{Nitrogen fertilizer levels:}

Three nitrogen fertilizer levels: N1. $80 \mathrm{~kg} \mathrm{~N} / \mathrm{fed}$ then $\mathrm{N} 2.100 \mathrm{~kg} \mathrm{~N} / \mathrm{fed}$ at last N3. $120 \mathrm{~kg} \mathrm{~N} / \mathrm{fed}$. Nitrogen fertilizer was applied in the form of ammonium nitrate $(33.5 \% \mathrm{~N})$ at the three equal doses i.e. $1 / 3$ before first irrigation, $1 / 3$ before second irrigation and the last one before third irrigation. Phosphorus fertilizer was added during land preparation in the form of calcium superphosphate $\left(15.5 \% \mathrm{p}_{2} \mathrm{O}_{5}\right)$ at the rate of $200 \mathrm{~kg} / \mathrm{fed}$. Potassium sulphate fertilizer $(50 \%$ $\mathrm{k}_{2} \mathrm{O}+18 \%$ silver) at the rate of $50 \mathrm{~kg} / \mathrm{fed}$ was applied in two equal

doses $25 \mathrm{~kg}$ at the first irrigation and the other before third irrigation. Thinning sugar beet took place after 45 days after sowing to one plant/hill. The other agronomic practices of growing wheat with sugar beet were applied as recommendation in Sers El - lain region. The date of agriculture practices in both season are presented in Table (3).

Table 3. Cultural practices of wheat sown and harvest with sugar beet in 2013/2014 and 2014/2015 seasons.

\begin{tabular}{|c|c|c|}
\hline \multirow{2}{*}{ Cultural practices } & \multicolumn{2}{|c|}{ Seasons } \\
\hline & $2013 / 2014$ & $2014 / 2015$ \\
\hline Sowing $1^{\text {st }}$ date of wheat with sugar beet & 30.10 .2013 & 28.10 .2014 \\
\hline Sowing $2^{\text {nd }}$ date of wheat. & 22.11.2013 & 23.11.2014 \\
\hline Sowing $3^{\text {d date of wheat. }}$ & 16.12 .2013 & 14.12.2014 \\
\hline Harvesting $1^{\text {st }}$ date of wheat. & 21.4.2014 & 20.4.2015 \\
\hline Harvesting $2^{\text {nd }}$ date of wheat. & 28.4.2014 & 25.4.2015 \\
\hline Harvesting $3^{d}$ date of wheat & 15.5.2014 & 10.5.2015 \\
\hline Harvesting sugar beet. & 20.5.2014 & 16.5.2015 \\
\hline
\end{tabular}


The studied characteristics were:

I. Sugar beet characters:

Top yield/fed (ton), root yield/fed (ton), biological yield/fed (ton) and sugar yield/fed (ton).

\section{Wheat characters}

Grain yield/fed (ton), straw yield /fed (ton) and biological yield/fed (ton).

III. Competitive relationships and yield advantages:

1. Land equivalent ratio (LER):

Land equivalent ratio (L.E.R) is calculated as the sum of the fraction of the yields of intercrops relative to their sole crop yields. (Willey 1979).

$$
L E R=\frac{Y a b}{Y a a}+\frac{Y b a}{Y b b}
$$

Where:

$\mathbf{Y a b}=$ yield of intercropped sugar beet, (in combination with b).

Yaa $=$ yield of pure sugar beet.

$\mathbf{Y b a}=$ yield of intercropped wheat, (in combination with a).

$\mathbf{Y b b}=$ yield of pure wheat.

\section{Relative crowding coefficient (K):}

If a species has coefficient less, equal to or greater than one, it means it has produced less yield, the same yield or more yield than "expected" respectively.

To determine if there is a yield advantage of mixing, the product of the coefficient is formed by multiplying Kab $\times$ Kba.

If $\mathbf{K}>1$ there is a yield advantage.

If $\mathbf{K}=1$ there is no difference.

If $\mathbf{K}<1$ there is a yield disadvantage.

Relative crowding coefficient for both crops were determined according to the following formula:

For species (A) in a mixture with species (B) (De Wit1960)

$$
\begin{gathered}
K a b=\frac{Y a b \times Z b a}{(Y a a-Y a b) \times Z a b} \\
K b a=\frac{Y b a \times Z a b}{(Y b b-Y b a) \times Z b a} \\
K=K a b \times K b a
\end{gathered}
$$

Where:

Yaa= pure stand of species (A).

$\mathbf{Y b b}=$ pure stand of species (B).

$\mathbf{Y a b}=$ mixture yield of species (A) in combination with (B). $\mathbf{Y b a}=$ mixture yield of species (B) in combination with (A). $\mathbf{Z a b}=$ Sown proportion of species (A) in mixture with (B). $\mathbf{Z b a}=$ Sown proportion of species (B) in mixture with (A).

3. Aggressivity (A):
An aggressivity value of zero indicates that the component species are equally competitive. For any other situation, both species will have the same numerical value, but the sign of the dominant species will be positive and that of the dominated will be negative. The greater the numerical value the bigger the difference in competitive abilities and the bigger the difference between actual and "expected" yields.

It was proposed by Mc Gillchrist (1965). It gives a sample measure of how much the relative yield increase in species (A) is greater than of species (B). Aggressivity is determined according to the following formula:

$$
\begin{aligned}
\text { Aab }=\frac{\text { Mixture yield of } A}{\text { Expected yield of } A} \\
-\frac{\text { Mixture yield of } B}{\text { Expected yield of } B}
\end{aligned}
$$

$$
A a b=\frac{Y a b}{Y a a \times Z a b}-\frac{Y b a}{Y b b \times Z b a}
$$

$$
A b a=\frac{Y b a}{Y b b \times Z b a}-\frac{Y a b}{Y a a \times Z a b}
$$

\section{Cereal units and Economic return. \\ 1. Cereal units/fed:}

Cereal units were recorded by Brockhaus (1962). Cereal units of all agriculture products for each crop were evaluated based on starch value. This measure avoids fluctuation of agricultural products prices which occurred from time. Each $100 \mathrm{Kg}$ of rye, barley, wheat and oat are considered standard having one unit. The products of sugar beet and wheat were evaluated as follows:

- Each $100 \mathrm{Kg}$ of sugar beet roots $=0.25$ unit.

- Each $100 \mathrm{Kg}$ of sugar beet tops = 0.10 unit.

- Each $100 \mathrm{Kg}$ of wheat grain = one unit.

- Each $100 \mathrm{Kg}$ of wheat straw = 0.10 unit.

- Statistical analysis:

Mean data collected were statistically analyzed in combined analysis according to Gomez and Gomez (1984). Treatment means were compared using least significant difference (L.S.D at 5\%) test as outlined by waller and Duncan(1969). All statistical analysis performed using analysis of variance technique by "MSTAT - C" computer soft ware 1990.

\section{Results and Discussion}

III. Competitive relationships and yield advantages:

1. Effect of sowing dates on:

1.1. Land equivalent ratio (LER): 
Data in Table (4) revealed that when wheat was planted at different sowing dates with sugar beet increased land usage in combined analysis. Results indicated that Ls values of sugar beet were higher than those of wheat Lw over all intercropping patterns. Relative yield of sugar beet increased by delaying wheat sowing date with sugar beet. Sugar beet Ls were $0.86,0.91$ and 0.93 , whereas wheat $(\mathrm{Lw})$ were 0.36 , 0.39 and 0.33 when wheat was intercropped with sugar beet at the same time, first irrigation and second irrigation respectively, It is evident that sugar beet was the better contributor in all sowing dates. On the other hand, total LER exceeded one under sowing dates. The highest value was (1.30) obtained by planting wheat with sugar beet at the first irrigation followed by planting wheat with sugar beet of the second irrigation (1.25) and the lowest values when wheat was planted with sugar at simultaneously. It could be concluded that intercropping wheat with sugar beet at the first irrigation is recommended for better land usage. Sanaa Saad(2007) when intercropping faba bean with sugar beet at different sowing dates $\left(1^{\text {st }}\right.$ Nov., $15^{\text {th }}$ Nov. and $1^{\text {st }}$ Dec.) showed that (L beet) values were increased by delaying sowing date of faba bean, but decreased ( $\mathrm{L}$ faba) and (LERs) for both crops, the values of LER were 1.40, 1.37 and 1.30 in the first season and 1.30,1.29 and 1.25 in the second season, respectively.

\subsection{Relative crowding coefficient $(K)$ :}

Results in Table (4) showed that delaying wheat sowing date with sugar beet achieved yield advantage in combined analysis. The best result was achieved by planting wheat at the second irrigation of sugar beet followed by at the first irrigation and at simultaneously showed the lowest value where $\mathrm{K}$ reached 8.77, 6.95 and 3.56, respectively.

It is quite evident from the results that sugar beet coefficient (Ks) exceeded one and increased by delaying wheat sowing date up to the second irrigation. Whereas wheat coefficient $(\mathrm{Kw})$ exceeded one and increased by delaying wheat sowing date to the second irrigation. This result indicated clearly that sugar beet was the better contributor under sowing dates of wheat with sugar beet. Sanaa Saad(2007) when intercropping faba bean with sugar beet at different sowing dates $\left(1^{\text {st }}\right.$ Nov., $15^{\text {th }}$ Nov. and $1^{\text {st }}$ Dec.) found that (K beet) were increased by delaying sowing date, but ( $\mathrm{K}$ faba) were decreased, where $\mathrm{K}$ values were 5.20, 5.78 and 6.14 in the first season and $4.14,4.28$ and 3.54 in the second season, respectively. 1.3. Aggressivity(A):

Results in Table (4) indicated that aggressivity(A) among sugar beet and wheat increased by delaying wheat sowing date from simultaneously to first irrigation. Whereas, delaying sowing date from first to second irrigation decreased aggressivity between both components. The results indicated that wheat "the over story" intercrop has higher competitive abilities than sugar beet as the "under story" component. So, wheat was the dominant intercrop component and sugar beet was the dominated intercrop under different sowing dates. Sanaa Saad(2007) reported that aggressivity values of sugar beet were positive (dominant) with delaying faba bean sowing date up to $1^{\text {st }}$ Dec. whereas, aggressivity values of faba bean were positive (dominant) at earliest sowing date of faba bean with sugar beet.

Table 4. Effect of sowing dates of wheat with sugar beet on LER, K and A, in combined analysis for (2013/2014 and 2014/2015) seasons.

\begin{tabular}{ccccccccc}
\hline Sowing dates & LER S & LER W & LER & KS & KW & K & As & Aw \\
\hline D1 & 0.856 & 0.355 & 1.211 & 1.864 & 1.904 & 3.549 & -0.478 & 0.478 \\
D2 & 0.909 & 0.389 & 1.298 & 3.167 & 2.195 & 6.952 & -0.555 & 0.555 \\
D3 & 0.926 & 0.325 & 1.251 & 5.280 & 1.661 & 8.770 & -0.251 & 0.251 \\
\hline L.S.D. 5\% & 0.003 & 0.001 & 0.004 & 1.008 & 0.004 & 1.182 & 0.008 & 0.008 \\
\hline
\end{tabular}

D1 Sowing Wheat with Sugar.

D2 Sowing Wheat $1^{\text {st }}$ Irrigation.

D3 Sowing Wheat $2^{\text {nd }}$ Irrigation.

\section{Effect of wheat intercropping patterns with sugar beet on:}

\subsection{Land equivalent ratio (LER):}

Results in Table (5) revealed that intercropping wheat and sugar beet when both species were planted under different intercropping patterns, increased land usage in combined, Sugar beet (Ls) in ridges exceeded than (Ls) in beds either with wheat $25 \%$ or $33.3 \%$ plant density of it is pure stand. Wheat (Lw) under intercropping patterns including wheat $33.3 \%$ plant density exceeded than intercropping patterns including wheat $25 \%$. In general sugar beet (Ls) produced higher yields than wheat $(\mathrm{Lw})$ in all intercropping patterns. Land usage recorded the highest value with intercropping pattern $(100 \%+$ $33.3 \%$ ) sugar beet/ wheat in ridges (1.28) and the lowest value of LER was obtained with $(100 \%+25 \%)$ intercropping pattern in beds (1.23). These results may be due to the increase in wheat seed rate from $25 \%$ to $33.3 \%$ with sugar beet $100 \%$. These results were coincided with obtained by Abd EL-Gwad et al.(2008), Badr(2013), Dina EL-Sherief and Hala Shehata (2015). While Abou - Elela(2012) found that the highest values of LER(1.31 and 1.25) when intercropping $25 \%$ wheat on the top of the second bed of sugar beet in both seasons, respectively.

2.2. Relative crowding coefficient (K): 
Data in Table (5) showed that intercropping sugar beet with wheat under different intercropping patterns exceed relative crowding coefficient $(\mathrm{K})$ and yield advantageous in combined analysis. The highest results was obtained by intercropping pattern which including wheat $25 \%$ and $33.3 \%$ in ridge width $(60$ $\mathrm{cm})$ where $(\mathrm{K})$ value reached (9.51) and (6.19) and the lowest values were obtained with treatments included wheat $25 \%$ and $33.3 \%$ at terraces $(120 \mathrm{~cm})$ where $(\mathrm{K})$ value reached (5.33). It is quite evident from data in Table(5) that sugar beet coefficient (Ks) achieved higher values compared with wheat coefficient $(\mathrm{Kw})$, where sugar beet (Ks) values ranged from (2.76) to (4.99) whereas, wheat $(\mathrm{Kw})$ values ranged between (1.91) and (1.94). Therefore, data indicated clearly that sugar beet (Ks) was more contributor compared with wheat $\mathrm{Kw}$ in all intercropping patterns. Similar results were reported by Toaima(2006), Attia et al.(2007) and Abd EL-Zaher et al.(2009). Whereas Abou Elela(2012) showed the highest values of RCC (12.99 and 5.36) when intercropping $25 \%$ wheat on the top of the second bed of sugar beet in both seasons, respectively.

\subsection{Aggressivity (A):}

Data revealed that wheat was the dominant whereas, sugar beet was dominated in all intercropping patterns as shown in combined analysis Table (5). Data revealed that (A) values far from zero, so intercropping wheat with sugar beet under different intercropping patterns increased competitive abilities and leading to be dominant component in all intercropping patterns. Similar results were reported by Badr(2013), but Ibrahim et al.(2008) found opposite results for aggressivity, they found that sugar beet was dominant component whereas; wheat was dominated component for aggressivity. While, Hala Shehata (2015) reported that aggressivity values of sugar beet were positive (dominant) at three intercropping patterns and wheat was positive dominant at one in first season. Simultaneously aggressivity values of sugar beet and wheat behaved opposite trend in the second season.

Table 5. Effect of intercropping patterns of wheat with sugar beet on LER, K and A, in combined analysis for (2013/2014 and 2014/2015) seasons.

\begin{tabular}{ccccccccc}
\hline Patterns & LER S & LER W & LER & KS & KW & K & As & Aw \\
\hline S1 & $\mathbf{0 . 9 2}$ & $\mathbf{0 . 3 2}$ & $\mathbf{1 . 2 5}$ & $\mathbf{4 . 9 9}$ & $\mathbf{1 . 9 1}$ & $\mathbf{9 . 5 1}$ & $\mathbf{- 0 . 4 5}$ & $\mathbf{0 . 4 5}$ \\
S2 & $\mathbf{0 . 9 1}$ & $\mathbf{0 . 3 3}$ & $\mathbf{1 . 2 3}$ & $\mathbf{2 . 7 5}$ & $\mathbf{1 . 9 4}$ & $\mathbf{5 . 3 3}$ & $\mathbf{- 0 . 5 0}$ & $\mathbf{0 . 5 0}$ \\
S3 & $\mathbf{0 . 8 9}$ & $\mathbf{0 . 3 9}$ & $\mathbf{1 . 2 8}$ & $\mathbf{3 . 2 4}$ & $\mathbf{1 . 9 1}$ & $\mathbf{6 . 1 9}$ & $\mathbf{- 0 . 3 7}$ & $\mathbf{0 . 3 7}$ \\
S4 & $\mathbf{0 . 8 7}$ & $\mathbf{0 . 3 9}$ & $\mathbf{1 . 2 6}$ & $\mathbf{2 . 7 6}$ & $\mathbf{1 . 9 3}$ & $\mathbf{5 . 3 3}$ & $\mathbf{- 0 . 4 0}$ & $\mathbf{0 . 4 0}$ \\
\hline L.S.D. 5\% & $\mathbf{0 . 0 0 6}$ & $\mathbf{0 . 0 0 1}$ & $\mathbf{0 . 0 0 6}$ & $\mathbf{0 . 4 7 5}$ & $\mathbf{0 . 0 0 4}$ & $\mathbf{0 . 6 1 6}$ & $\mathbf{0 . 0 1 0}$ & $\mathbf{0 . 0 1 0}$ \\
\hline
\end{tabular}

S1 $(100 \%$ Sugar $+25 \%$ Wheat $)$ ridges.

S2 $(100 \%$ Sugar $+25 \%$ Wheat $)$ beds.

S3 $(100 \%$ Sugar $+33.3 \%$ Wheat $)$ ridges.

S4 (100\% Sugar $+33.3 \%$ Wheat) beds.

\section{Effect of nitrogen fertilizer levels on: \\ 3.1. Land equivalent ratio (LER):}

Data in Table (6) revealed that land equivalent ratio (LER) values increased land usage by adding $\mathrm{N}$ fertilization in combined analysis. The increases of land usage were 24,27 and $26 \%$ by increasing nitrogen fertilizer level from 80 to 100 and $120 \mathrm{Kg}$ $\mathrm{N} /$ fed. Data showed that (Ls) was more contributor for land usage compared with (Lw). Land usage of sugar beet (Ls) was 70.96, 71.65 and $71.42 \%$ of sugar beet pure stand, whereas land usage of wheat (Lw) were $29.03,28.34$ and $28.57 \%$ of wheat pure stand by adding 80, 100 and $120 \mathrm{Kg} \mathrm{N} / \mathrm{fed}$, respectively. Data revealed that the highest value of LER (1.27) was obtained by adding $100 \mathrm{Kg}$ N/fed followed by $120 \mathrm{Kg}$ $\mathrm{N} /$ fed (1.26) and the lowest value was (1.24) showed with $80 \mathrm{Kg} \mathrm{N} / \mathrm{fed}$. It could be concluded that no differences between 100 and $120 \mathrm{Kg} \mathrm{N} /$ fed to obtained the best land usage with intercropping wheat by 25 or $33.3 \%$ plant density of its pure stand. Similar results were also reported by Abd EL-Gwad et al.(2008), Ibrahim et al.(2008) and $\operatorname{Badr}(2013$.

\subsection{Relative crowding coefficient $(K)$ :}

Data presented in Table (6) clearly indicated that increasing nitrogen rates from 80 to 100 up to $120 \mathrm{Kg}$ $\mathrm{N} /$ fed. improved yield advantageous of sugar beet (Ks) and wheat $(\mathrm{Kw})$ in combined analysis. Relative crowding coefficient $(\mathrm{K})$ was more than one and maximum value achieved (8.69) at $100 \mathrm{Kg} \mathrm{N} / \mathrm{fed}$ followed by $120 \mathrm{Kg} \mathrm{N} / \mathrm{fed} \mathrm{(6.35)} \mathrm{whereas} \mathrm{the}$ minimum value (4.79) was obtained at $80 \mathrm{Kg} \mathrm{N} / \mathrm{fed}$ Relative crowding coefficient of sugar beet $(\mathrm{Ks})$ was more contributor for yield advantageous than of wheat $(\mathrm{Kw})$. Sugar beet yield advantageous (Ks) were 2.52, 4.50 and 3.29, whereas (Kw) 1.9, 1.93 and 1.93at 80,100 and $120 \mathrm{Kg} \mathrm{N} / \mathrm{fed}$, respectively. It is evident that adding $100 \mathrm{Kg} \mathrm{N} / \mathrm{fed}$. gave the highest values (4.50 and 1.93) for crowding coefficient of sugar beet (Ks) and wheat (Kw), respectively. Attia et al.(2007), Abd EL-Zaher et al.(2009) and Badr(2013). They found that the best values of $(\mathrm{K})$ was ranged from 4.43 to 10.98 with cropping 3 rows of wheat with sugar beet.

\subsection{Aggressivity (A):}

Results in Table (6) showed that wheat was the dominant component in all treatments, whereas sugar beet was the dominated in combined. Aggressivity 
values were increased where sugar beet and wheat fertilized at a rate of $80 \mathrm{Kg} \mathrm{N} / \mathrm{fed}$ and there is no different in aggressivity values where both component crops at a rate of 100 or $120 \mathrm{Kg} \mathrm{N} / \mathrm{fed}$. The present results indicated that wheat could be considered as a component with higher competitive abilities when both crops fertilized by N. fertilization and increased
$\mathrm{N}$ fertilizer level up to $120 \mathrm{Kg} \mathrm{N} / \mathrm{fed}$., lead to increase in growth and yield components of wheat. Similar results were reported by Badr (2013). Whereas, Attia et al.(2007). Abd EL-Zaher et al.(2009) showed opposite results they reported that sugar beet was the dominant component and wheat or barley was the dominated components.

Table 6. Effect of N. levels of wheat with sugar beet on LER, K and A, in combined analysis for (2013/2014 and 2014/2015) seasons.

\begin{tabular}{cccccccccc}
\hline N.levels & LER S & LER W & LER & KS & KW & K & As & Aw \\
\hline N1 & $\mathbf{0 . 8 8}$ & $\mathbf{0 . 3 6}$ & 1.24 & 2.52 & 1.90 & 4.79 & $-\mathbf{0 . 4 4}$ & $\mathbf{0 . 4 4}$ \\
N2 & $\mathbf{0 . 9 1}$ & $\mathbf{0 . 3 6}$ & 1.27 & 4.50 & $\mathbf{1 . 9 3}$ & $\mathbf{8 . 6 9}$ & $\mathbf{- 0 . 4 2}$ & $\mathbf{0 . 4 2}$ \\
N3 & $\mathbf{0 . 9 0}$ & $\mathbf{0 . 3 6}$ & 1.26 & $\mathbf{3 . 2 9}$ & $\mathbf{1 . 9 3}$ & $\mathbf{6 . 3 5}$ & $\mathbf{- 0 . 4 2}$ & $\mathbf{0 . 4 2}$ \\
\hline L.S.D.5\% & $\mathbf{0 . 0 0 6}$ & $\mathbf{0 . 0 0 1}$ & $\mathbf{0 . 0 0 6}$ & $\mathbf{0 . 5 2 4}$ & $\mathbf{0 . 0 0 6}$ & $\mathbf{0 . 6 3 2}$ & $\mathbf{0 . 0 0 9}$ & $\mathbf{0 . 0 0 9}$ \\
\hline
\end{tabular}

N1 $80 \mathrm{Kg}$ N/fed.

N2 $100 \mathrm{Kg} \mathrm{N} / \mathrm{fed}$.

N3 $120 \mathrm{Kg} \mathrm{N} / \mathrm{fed}$.

4. Effect of the interaction between sowing date and wheat intercropping patterns $(\mathrm{D} \times \mathrm{S})$ :

\subsection{Land equivalent ratio:}

Data presented in Table (7) revealed that land equivalent ratio achieved positive results by the interaction between wheat sowing dates with sugar beet and intercropping patterns in combined analysis. The highest value (1.34) of land usage was obtained by intercropping wheat $33.3 \%$ in ridges with the first irrigation of sugar beet (D2 $\times$ S3) where, land usage increased by $34 \%$. Whereas, the lowest value (1.20) for land usage was showed with wheat and sugar beet at simultaneously and $(100 \%+25 \%)$ sugar beet/wheat at terraces $(\mathrm{D} 1 \times \mathrm{S} 2)$.

\subsection{Relative crowding coefficient $(K)$ :}

Data in Table (7) indicated that the interaction between sowing dates and intercropping patterns $(\mathrm{D} \times$ S) of wheat with sugar beet was advantageous in all treatments in combined analysis. The highest result 15.26 was achieved by planting wheat with sugar beet at the second irrigation of sugar beet and wheat $25 \%$ of its pure stand in ridges $60 \mathrm{~cm}$ wide $(\mathrm{D} 2 \times \mathrm{S} 3$ ) whereas, the lowest value (2.93) was obtained when wheat was planted and sugar beet with sowing irrigation of sugar beet $($ D1 $\times$ S4) Table $(7)$ revealed that values of sugar beet coefficient $(\mathrm{Ks})$ were ranged between 1.57 and 9.16, whereas values of wheat coefficient $(\mathrm{Kw})$ were ranged between 1.63 and 2.26. It is evident clearly that sugar beet was the better contributor to achieve yield advantageous than wheat.

Table 7. Interaction effect between sowing dates and intercropping patterns of wheat with sugar beet on LER, $\mathrm{K}$ and $\mathrm{A}$ in combined analysis for (2013/2014 and 2014/2015 seasons).

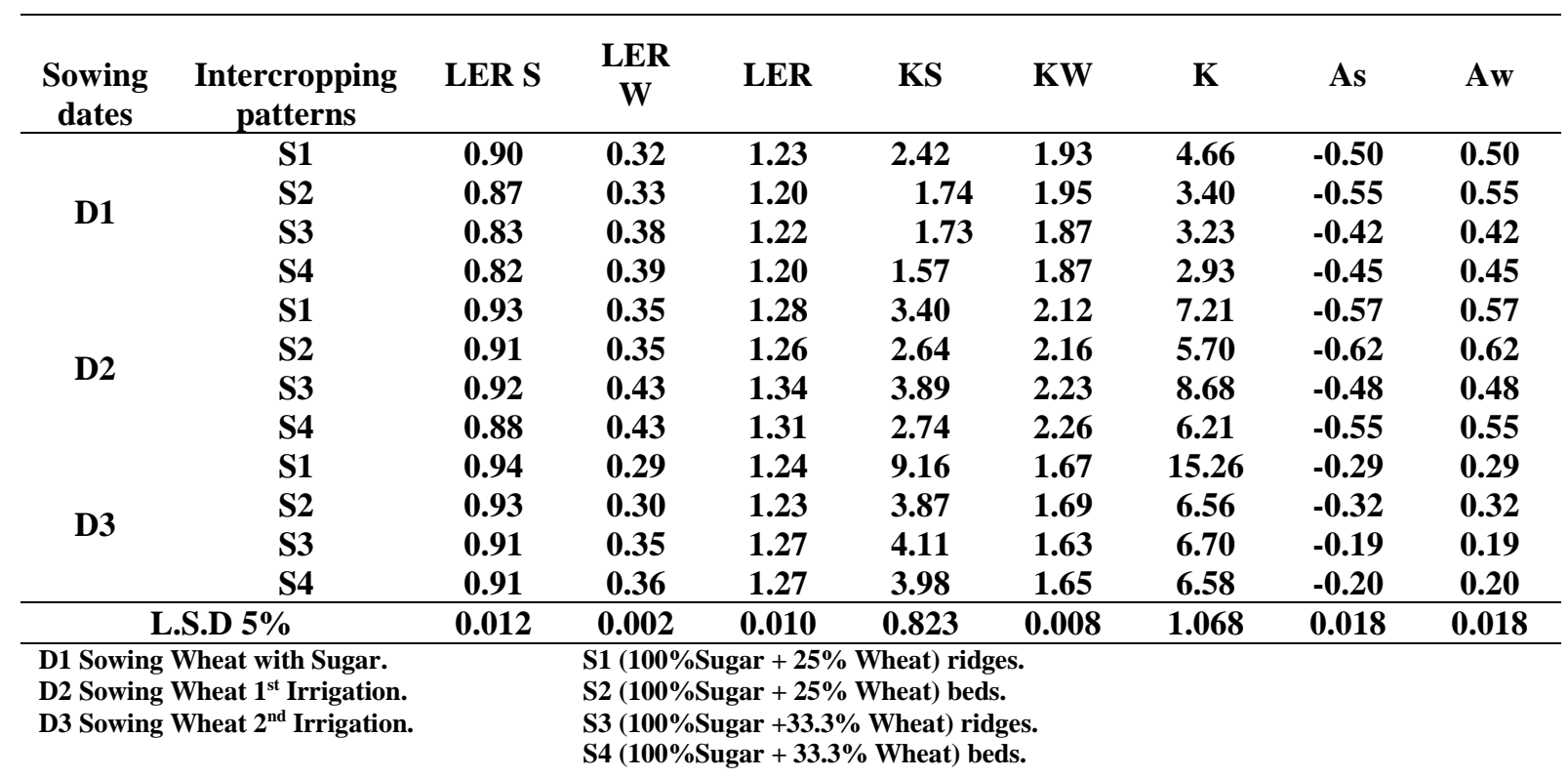




\subsection{Aggresivity(A):}

Results in Table (7) showed that wheat was the dominant intercrop component and sugar beet was the dominated in all treatments in combined analysis. The present results indicated clearly that wheat intercropping patterns with sugar beet just before the first irrigation of sugar beet increased competitive ability of wheat followed by intercropping patterns at planting irrigation of sugar beet and simultaneously $(\mathrm{D} 1 \times$ S2) competitive abilities of wheat was reduced at different intercropping patterns when wheat was planted just before the second irrigation of sugar beet $(\mathrm{D} 3 \times \mathrm{S} 3)$.

\section{Effect of the interaction between wheat sowing dates and $\mathrm{N}$ levels:}

\subsection{Land equivalent ratio (LER):}

Results in Table(8) showed that wheat sowing date with sugar beet when both species were fertilized by 80 to 100 up to $120 \mathrm{Kg} \mathrm{N} / \mathrm{fed}$ increased land usage in all treatments in combined analysis. Data revealed that land usage of sugar beet (Ls) was better contributor in land equivalent ratio (LER) than land usage of wheat $(\mathrm{Lw})$. The highest value of land usage (1.31) was obtained when wheat was planted with the first irrigation of sugar beet and 100 or $120 \mathrm{Kg} \mathrm{N} / \mathrm{fed}$ $(\mathrm{D} 2 \times \mathrm{N} 2$ or N3). On the other hand the lowest value of land usage (1.19) was obtained when wheat planted with sowing sugar beet and $80 \mathrm{Kg} \mathrm{N}$ fertilizer level $(\mathrm{D} 1 \times \mathrm{N} 1)$. In general, the second sowing date of wheat under different $\mathrm{N}$. fertilizer rate gave the highest values compared with other sowing dates and different N., fertilization levels.

\subsection{Relative crowding coefficient $(K)$ :}

Results in Table (8) showed that the interaction between wheat sowing dates with sugar beet and nitrogen fertilizer level achieved yield advantageous in all treatments. The best yield advantage was achieved with wheat planting date at the second irrigation of sugar beet and a rate of $100 \mathrm{Kg} \mathrm{N} / \mathrm{fed}(\mathrm{K})$ was 13.22 , simultaneously $(\mathrm{D} 3 \times \mathrm{N} 2)$ the lowest value 2.92 of $(\mathrm{K})$ was showed when wheat was planted with sugar beet at the sowing irrigation of sugar beet and a rate of $80 \mathrm{Kg} \mathrm{N} / \mathrm{fed}(\mathrm{D} 1 \times \mathrm{N} 1)$. It is quite evident from the results that sugar beet coefficient (Ks) or wheat coefficient $(\mathrm{Kw})$ exceeded one in all treatments.

\subsection{Aggressivity(A):}

Data presented in Table (8) showed that wheat was the dominant component crop and sugar beet was the dominated component crop in all treatments due to the interaction between wheat sowing dates and $\mathrm{N}$. fertilizer levels in combined analysis. Nitrogen fertilizer levels (80,100 and $120 \mathrm{Kg} \mathrm{N} / \mathrm{fed}$.) decreased aggressivity values the highest values $(0.56)$ when wheat was planted with sugar beet at the first irrigation of sugar beet $(\mathrm{D} 2 \times \mathrm{N} 1)$ followed by nitrogen fertilizer levels with planting wheat and sugar beet at the first irrigation of sugar beet, (D2 $\times \mathrm{N} 2$ or N3) and simultaneously the lowest values of competitive abilities between sugar beet and wheat with the same of nitrogen levels when wheat was planted just before the second irrigation of sugar beet $(\mathrm{D} 3 \times \mathrm{N} 2$ orN3). Results indicated clearly that wheat could be considered as the component with higher competitive abilities when wheat and sugar beet fertilized at a rate of 100 or $120 \mathrm{Kg} \mathrm{N} / \mathrm{fed}$. under different sowing dates of wheat with sugar beet.

Table 8. Interaction effect between sowing dates and N. levels of wheat with sugar beet on LER, K and A in combined analysis for (2013/2014 and 2014/2015 seasons).

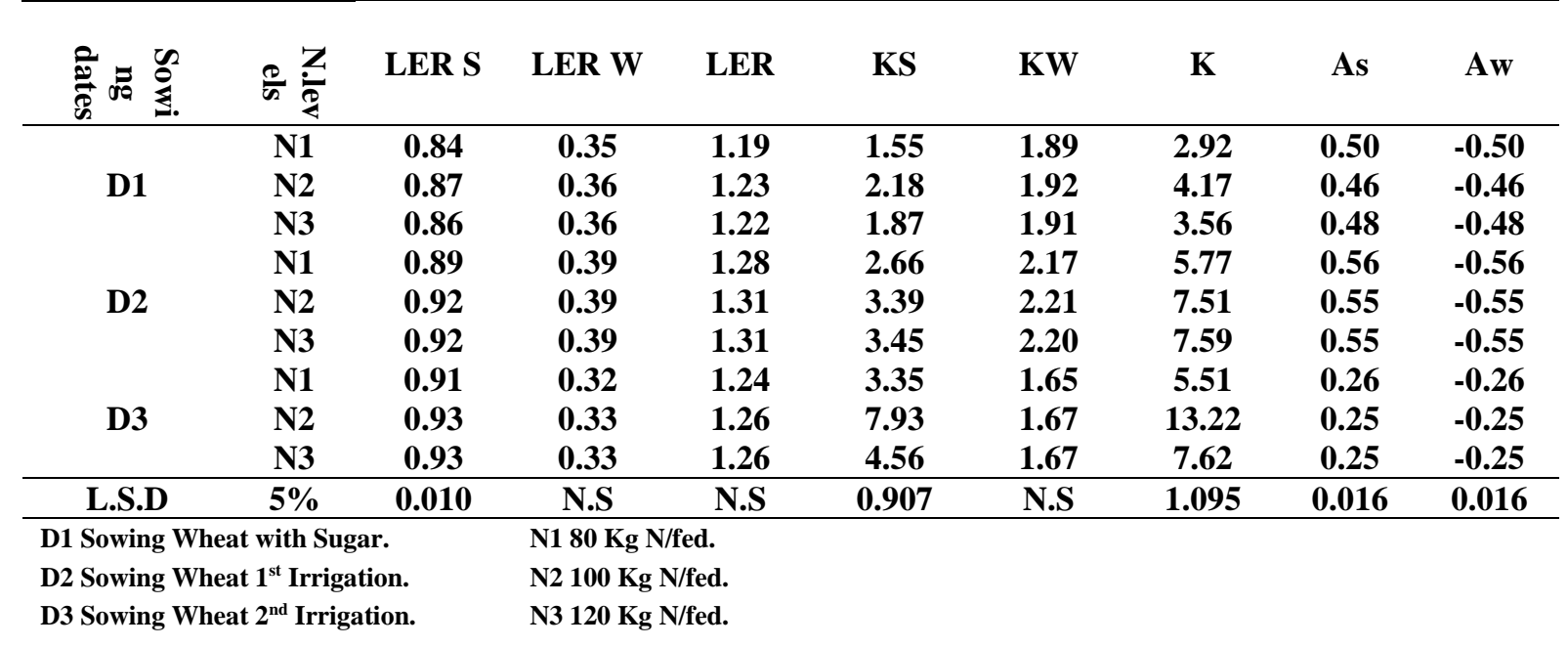

6. Effect of the interaction between intercropping patterns and $N$. levels on $(S \times N)$ : 6.1. Land equivalent ratio (LER):
Results in Table (9) revealed that land equivalent ratio (LER) were exceeded one in all treatments due to the interaction between the intercropping patterns 
in ridges and N., fertilizer levels in combined analysis. Land usage value achieved the highest value (1.29) when intercropping pattern $(100 \%+33.3 \%)$ sugar beet/wheat in ridges at a rate of 100 or $120 \mathrm{Kg} \mathrm{N} / \mathrm{fed}$ $(\mathrm{S} 3 \times \mathrm{N} 2$ or N3) where, LER value increased by $29 \%$ followed by intercropping patterns $(100 \%+33.3 \%)$ sugar beet/wheat at terraces and fertilized by $100 \mathrm{Kg}$ N/fed which increased LER by $28 \%$. Whereas, the lowest value (1.22) was obtained with intercropping pattern $(100 \%+25 \%)$ sugar beet/wheat at terraces and fertilized by $80 \mathrm{Kg}$ N/fed $(\mathrm{S} 2 \times \mathrm{N} 1)$ where LER value increased by $22 \%$. Sugar beet was a better contributor in LER and produced higher values in all treatments than wheat. There is no significant differences between intercropping patterns $(100 \%+33.3 \%)$ sugar beet/wheat at ridges or terraces and fertilized by $100 \mathrm{Kg} \mathrm{N} /$ fed. Similar results were reported by Ibrahim et al.(2008); on the other hand $\operatorname{Badr}(\mathbf{2 0 1 3})$ reported that LERs were ranged between 1.48 and 1.92 obtained when intercropping $(100 \%+50 \%)$ sugar beet/wheat with no significant between 120 and $140 \mathrm{Kg} \mathrm{N} / \mathrm{fed}$.

6.2. Relative crowding coefficient $(K)$ :

Data in Table (9) indicated that the interaction between intercropping patterns and $\mathrm{N}$. fertilizer levels achieved yield advantage in combined analysis. The best result was obtained by intercropping wheat with sugar beet $(100 \%+25 \%)$ at terraces and fertilization by a rate of $100 \mathrm{Kg} \mathrm{N} / \mathrm{fed}(\mathrm{S} 2 \times \mathrm{N} 2)$ where $(\mathrm{K})$ value reached 4.21 and the lowest value (3.98) was showed by intercropping pattern (sugar beet $100 \%+$ wheat $33.3 \%$ ) at terraces and fertilized by $80 \mathrm{Kg} \mathrm{N} /$ fed (S4 $\times$ N1), Results indicates clearly that sugar beet has more competitive abilities than wheat in all cases. These results may be due to plant density of sugar beet was $100 \%$ whereas, wheat plant density was ranged between 25 and $33.3 \%$ of its pure stand. Results reported by Attia et al. (2007), Abd EL-Gwad et al. (2008), Ibrahim et al. (2008) and Badr (2013) showed that RCC resulting from intercropping of both species with different nitrogen levels excepted one indicating yield advantages.

6.3. Aggressivity (A):

Data in Table (9) indicated that wheat gave positive values of (A), whereas, sugar beet gave negative values of $(A)$ in all treatments because of the interaction between intercropping patterns and $\mathrm{N}$, levels $(\mathrm{S} \times \mathrm{N})$ in combined. So, wheat is considered dominant component crop and sugar beet was dominated component crop in all interaction treatments. It is quite evident that all the combination between intercropping patterns and nitrogen levels under study increased competitive abilities between wheat and sugar beet. Similar the results were recorded by Badr (2013), but Toaima (2006), Attia et al. (2007) and Abd EL-Gwad et al. (2008) revealed that sugar beet was dominant crop and wheat was dominated in both seasosns.

Table 9. Interaction effect between intercropping patterns and $\mathrm{N}$. levels of wheat with sugar beet on (LER, $K$ and A), in combined analysis for (2013/2014 and 2014/2015 seasons).

\begin{tabular}{|c|c|c|c|c|c|c|c|c|c|}
\hline 롱 웅 & $\frac{2}{\pi} \underset{\frac{3}{4}}{Z}$ & LER S & LER w & LER & KS & Kw & $\mathbf{K}$ & AGG S & AGG W \\
\hline \multirow{3}{*}{ S1 } & N1 & 0.91 & 0.319 & 1.23 & 2.14 & 1.88 & 4.03 & -0.46 & 0.46 \\
\hline & $\mathbf{N} 2$ & 0.93 & 0.323 & 1.26 & 2.19 & 1.92 & 4.19 & -0.45 & 0.45 \\
\hline & $\mathbf{N 3}$ & 0.93 & 0.322 & 1.25 & 2.18 & 1.92 & 4.18 & -0.45 & 0.45 \\
\hline \multirow{3}{*}{ S2 } & N1 & 0.90 & 0.323 & 1.22 & 2.12 & 1.91 & 4.05 & -0.49 & 0.49 \\
\hline & $\mathbf{N} 2$ & 0.91 & 0.327 & 1.24 & 2.15 & 1.95 & 4.21 & -0.49 & 0.49 \\
\hline & N3 & 0.91 & 0.326 & 1.23 & 2.14 & 1.94 & 4.15 & -0.50 & 0.50 \\
\hline \multirow{3}{*}{ S3 } & N1 & 0.87 & 0.387 & 1.25 & 2.12 & 1.89 & 4.01 & -0.39 & 0.39 \\
\hline & $\mathbf{N 2}$ & 0.90 & 0.389 & 1.29 & 2.18 & 1.92 & 4.19 & -0.36 & 0.36 \\
\hline & N3 & 0.90 & 0.388 & 1.29 & 2.19 & 1.91 & 4.18 & -0.35 & 0.35 \\
\hline \multirow{3}{*}{ S4 } & N1 & 0.85 & 0.389 & 1.24 & 2.08 & 1.91 & 3.98 & -0.42 & 0.42 \\
\hline & $\mathbf{N 2}$ & 0.89 & 0.391 & 1.28 & 2.17 & 1.94 & 4.20 & -0.38 & 0.38 \\
\hline & N3 & 0.88 & 0.391 & 1.27 & 2.15 & 1.94 & 4.17 & -0.39 & 0.39 \\
\hline \multicolumn{2}{|c|}{ L.S.D 5\% } & 0.021 & N.S & 0.012 & 1.048 & N.S & 1.395 & 0.018 & 0.018 \\
\hline \multicolumn{5}{|c|}{$\begin{array}{l}\text { S1 (100\% Sugar }+25 \% \text { Wheat) ridges. } \\
\text { S2 }(100 \% \text { Sugar }+25 \% \text { Wheat }) \text { beds. } \\
\text { S3 }(100 \% \text { Sugar }+33.3 \% \text { Wheat }) \text { ridges. }\end{array}$} & $\begin{array}{l}\text { N1 } 80 \text { K } \\
\text { N2 } 100 \\
\text { N3 } 120\end{array}$ & $\begin{array}{l}\text { fed. } \\
\text { //fed. } \\
\text { //fed. }\end{array}$ & & & \\
\hline
\end{tabular}

7. Effect of the interaction between sowing dates, intercropping patterns and $\mathrm{N}$. fertilizer levels on $(\mathrm{D} \times \mathrm{S} \times \mathrm{N})$ :

7.1. Land equivalent ratio (LER):

Data presented in Table (10) revealed that land equivalent ratio (LERs) were positively increased by the interaction between three factors under study in combined analysis. Data indicated that land usage exceeded one in all interaction treatments. The best value (1.36) was obtained with wheat sowing date with sugar beet at the first irrigation of sugar beet and intercropping patterns (sugar beet $100 \%$ + wheat 33.3 $\%)$ in ridges at a rate of $120 \mathrm{Kg} \mathrm{N}$./fed $(\mathrm{D} 2 \times \mathrm{S} 3 \times \mathrm{N} 3)$ and the lowest value (1.18) was obtained by wheat 
planting with sugar beet at sowing irrigation of sugar beet and intercropping patterns (sugar beet 100\% + wheat $33.3 \%$ ) either in ridges or terraces and with adding $80 \mathrm{Kg} \mathrm{N} /$ fed $(\mathrm{D} 1 \times \mathrm{S} 3$ or $\mathrm{S} 4 \times \mathrm{N} 1)$ in combined. Sugar beet was a better contributor in LER and produced higher values (Ls) were ranged between 66.94 and $76 \%$ of LERs as average of all treatments whereas, Lw of wheat ranged between 26.44 and $43.33 \%$ of LERs. Similar results was obtained by
Sanaa Saad(2007) found that the highest values of LER (1.51 and 1.45) were produced from intercropping faba bean plant on mid Nov. at the highest plant density (105 thousand/fed) and highest $\mathrm{N}$ fertilizer level $(100 \mathrm{Kg} / \mathrm{fed})$ in the first and second seasons, respectively when intercropping faba bean with sugar beet.

Table (10): Interaction effect between sowing dates, intercropping patterns and N. fertilizer levels of wheat on (LER, $K$ and A), in combined analysis for (2013/2014 and 2014/2015 seasons).

\begin{tabular}{|c|c|c|c|c|c|c|c|c|c|c|}
\hline $\begin{array}{c}\text { Sowing } \\
\text { dates }\end{array}$ & $\begin{array}{c}\text { Intercropping } \\
\text { patterns }\end{array}$ & $\begin{array}{c}\text { N. } \\
\text { Levels }\end{array}$ & $\begin{array}{c}\text { LER } \\
\mathbf{S}\end{array}$ & $\begin{array}{c}\text { LER } \\
\mathbf{W}\end{array}$ & LER & KS & KW & $\mathbf{K}$ & $\mathbf{A S}$ & $\mathbf{A W}$ \\
\hline \multirow{13}{*}{ D1 } & \multirow{3}{*}{ S1 } & N1 & 0.88 & 0.32 & 1.21 & 1.92 & 1.91 & 3.66 & -0.51 & 0.51 \\
\hline & & N2 & 0.92 & 0.33 & 1.25 & 2.94 & 1.95 & 5.71 & -0.49 & 0.49 \\
\hline & & N3 & 0.91 & 0.32 & 1.23 & 2.40 & 1.93 & 4.61 & -0.49 & 0.49 \\
\hline & \multirow{3}{*}{ S2 } & N1 & 0.86 & 0.33 & 1.19 & 1.64 & 1.93 & 3.17 & -0.55 & 0.55 \\
\hline & & N2 & 0.87 & 0.33 & 1.20 & 1.71 & 1.97 & 3.37 & -0.56 & 0.56 \\
\hline & & N3 & 0.88 & 0.33 & 1.21 & 1.87 & 1.96 & 3.66 & -0.54 & 0.54 \\
\hline & \multirow{4}{*}{ S3 } & N1 & 0.80 & 0.38 & 1.18 & 1.35 & 1.85 & 2.49 & -0.46 & 0.46 \\
\hline & & N2 & 0.86 & 0.39 & 1.25 & 2.18 & 1.88 & 4.09 & -0.39 & 0.39 \\
\hline & & N3 & 0.83 & 0.38 & 1.22 & 1.67 & 1.87 & 3.13 & -0.43 & 0.43 \\
\hline & & N1 & 0.79 & 0.38 & 1.18 & 1.29 & 1.86 & 2.40 & -0.47 & 0.47 \\
\hline & \multirow[t]{3}{*}{ S4 } & N2 & 0.85 & 0.39 & 1.23 & 1.88 & 1.88 & 3.52 & -0.41 & 0.41 \\
\hline & & N3 & 0.82 & 0.39 & 1.21 & 1.53 & 1.88 & 2.88 & -0.45 & 0.45 \\
\hline & & N1 & 0.92 & 0.34 & 1.26 & 2.99 & 2.09 & 6.25 & -0.57 & 0.57 \\
\hline \multirow{10}{*}{ D2 } & \multirow[t]{2}{*}{ S1 } & N2 & 0.93 & 0.35 & 1.28 & 3.50 & 2.13 & 7.46 & -0.58 & 0.58 \\
\hline & & N3 & 0.94 & 0.35 & 1.29 & 3.71 & 2.14 & 7.94 & -0.58 & 0.58 \\
\hline & \multirow{3}{*}{ S2 } & N1 & 0.90 & 0.35 & 1.24 & 2.22 & 2.13 & 4.72 & -0.62 & 0.62 \\
\hline & & N2 & 0.92 & 0.35 & 1.27 & 2.85 & 2.20 & 6.25 & -0.62 & 0.62 \\
\hline & & N3 & 0.92 & 0.35 & 1.27 & 2.84 & 2.16 & 6.15 & -0.61 & 0.61 \\
\hline & \multirow{4}{*}{ S3 } & N1 & 0.90 & 0.43 & 1.33 & 3.29 & 2.20 & 7.25 & -0.49 & 0.49 \\
\hline & & $\mathbf{N 2}$ & 0.92 & 0.43 & 1.35 & 3.86 & 2.25 & 8.69 & -0.49 & 0.49 \\
\hline & & N3 & 0.93 & 0.43 & 1.36 & 4.52 & 2.24 & 10.12 & -0.47 & 0.47 \\
\hline & & N1 & 0.86 & 0.43 & 1.29 & 2.16 & 2.24 & 4.83 & -0.57 & 0.57 \\
\hline & \multirow[t]{3}{*}{ S4 } & N2 & 0.90 & 0.43 & 1.33 & 3.36 & 2.28 & 7.64 & -0.53 & 0.53 \\
\hline \multirow{13}{*}{ D3 } & & N3 & 0.89 & 0.43 & 1.32 & 2.71 & 2.27 & 6.17 & -0.55 & 0.55 \\
\hline & & N1 & 0.93 & 0.29 & 1.22 & 3.42 & 1.66 & 5.66 & -0.30 & 0.30 \\
\hline & \multirow[t]{2}{*}{ S1 } & N2 & 0.95 & 0.30 & 1.25 & 9.04 & 1.67 & 15.10 & -0.28 & 0.28 \\
\hline & & N3 & 0.95 & 0.29 & 1.24 & 5.01 & 1.68 & 8.41 & -0.29 & 0.29 \\
\hline & \multirow{3}{*}{ S2 } & N1 & 0.93 & 0.30 & 1.23 & 3.77 & 1.68 & 6.31 & -0.31 & 0.31 \\
\hline & & N2 & 0.95 & 0.30 & 1.25 & 4.94 & 1.70 & 8.39 & -0.30 & 0.30 \\
\hline & & N3 & 0.92 & 0.30 & 1.21 & 2.91 & 1.71 & 4.97 & -0.35 & 0.35 \\
\hline & \multirow{4}{*}{ S3 } & N1 & 0.90 & 0.35 & 1.25 & 3.31 & 1.62 & 5.36 & -0.21 & 0.21 \\
\hline & & N2 & 0.91 & 0.35 & 1.26 & 3.60 & 1.64 & 5.89 & -0.20 & 0.20 \\
\hline & & N3 & 0.94 & 0.35 & 1.29 & 5.42 & 1.64 & 8.87 & -0.17 & 0.17 \\
\hline & & N1 & 0.89 & 0.36 & 1.24 & 2.91 & 1.63 & 4.75 & -0.22 & 0.22 \\
\hline & \multirow[t]{2}{*}{ S4 } & N2 & 0.92 & 0.36 & 1.27 & 4.14 & 1.67 & 6.90 & -0.21 & 0.21 \\
\hline & & N3 & 0.94 & 0.36 & 1.29 & 4.90 & 1.66 & 8.12 & -0.18 & 0.18 \\
\hline L.S.D & $5 \%$ & & 0.021 & N.S & 0.022 & 1.815 & N.S & 2.198 & 0.032 & 0.032 \\
\hline $\begin{array}{l}\text { D2 Sowin } \\
\text { D3 Sowin }\end{array}$ & $\begin{array}{l}\text { igar. } \\
\text { ation. } \\
\text { gation. }\end{array}$ & $\begin{array}{l}100 \% \mathrm{~S} \\
(100 \%\end{array}$ & -33.3 & at) & $\begin{array}{l}\mathrm{N} 18 \\
\mathrm{~N} 2 \\
\mathrm{~N} 3 \\
1\end{array}$ & $\begin{array}{l}\text { N/fed. } \\
\mathrm{g} \mathrm{N} / \mathrm{fed} \\
\mathrm{g} \mathrm{N} / \mathrm{fed} .\end{array}$ & & & & \\
\hline
\end{tabular}

7.2. Relative crowding coefficient $(K)$ :

Data presented in Table (10) indicated that sugar beet and wheat under different combination between three factors under study was advantageous in all interaction treatments in combined analysis. The best result was achieved with wheat planting before the second irrigation of sugar beet and intercropping pattern $(100 \%+25 \%)$ sugar beet/wheat in ridges $(60$ 
$\mathrm{cm}$ wide) and fertilized by $100 \mathrm{Kg} \mathrm{N} /$ fed $(\mathrm{D} 3 \times \mathrm{S} 1 \times$ $\mathrm{N} 2$ ), which was (15.10). On the other hand, the lowest value 2.40 was showed with wheat planting with sugar beet at sowing irrigation and intercropping pattern (sugar beet $100 \%$ + wheat $33.3 \%$ ) at terraces and $\mathrm{N} 1$ $80 \mathrm{Kg} \mathrm{N} / \mathrm{fed}$ (D1 S4 N1) in combined analysis, sugar beet was the best component in all cases with higher (Ks) values. This result that sugar beet has more competitive abilities than wheat and led to a great increase in $\mathrm{K}$ under all combination between three factors under study in combined. Sanaa Saad(2007) revealed that the maximum values for $\mathrm{K}$ were 9.51 and 6.94, obtained from intercropping faba bean and sugar beet at sowing date $1^{\text {st }}$ Nov. at the highest plant density (105 thousand/fed) and $80 \mathrm{Kg} \mathrm{N} /$ fed in the first season, whereas in the second season $\mathrm{K}$ value was 6.94 achieved from intercropping faba bean with sugar beet at mid Nov. at the highest plant density (105.000/fed) and $100 \mathrm{Kg} \mathrm{N} /$ fed when intercropping faba bean with sugar beet.

\subsection{Aggressivity (A):}

Data presented in Table (10) revealed that wheat was the dominant component in all cases and sugar beet was the dominated component in combined analysis. In general, aggressivity values were increased with wheat planting at first irrigation of sugar beet under combination between different intercropping pattern and nitrogen fertilizer rates 0.62
$(\mathrm{D} 2 \times \mathrm{S} 2 \times \mathrm{N} 1$ or N2). Whereas, the best values 0.17 of $($ A) were obtained at interaction treatment $($ D3 $\times$ S3 $\times$ N3). Sanaa Saad(2007) showed that aggressivity values of sugar beet were positive (dominant) and faba bean were negative dominated with delaying faba bean sowing date up the $1^{\text {st }}$ Dec. under any plant density and $\mathrm{N}$ fertilizer level in both seasons. whereas, aggressivity were negative for sugar beet and positive for faba bean at earliest sowing date of Faba bean with the moderate and highest plant density under different $\mathrm{N}$. fertilizer levels in both seasons when intercropping faba bean with sugar beet.

\section{II- Cereal units:}

1. Effect of wheat sowing dates with sugar beet:

Data presented in Table (11) revealed that cereal units/fed were significantly affected by wheat sowing dates with sugar beet in combined analysis. Wheat planting just before second irrigation of sugar beet gave the highest value, where cereal units was $110.62 /$ fed as a total of both crops (main and by products), followed by wheat sowing date with the first irrigation (110.05) cereal units/fed and simultaneously wheat planted with sowing irrigation of sugar beet gave the lowest value (102.90) cereal units/fed which was the least than sugar beet alone (105.84) cereal units/fed.

Table (11): Effect of sowing dates of wheat with sugar beet on total cereal units (root, top, grain, and straw yields/fed.) in combined analysis for (2013/2014 and 2014/2015) seasons.

\begin{tabular}{|c|c|c|c|c|c|}
\hline \multirow[b]{3}{*}{ Sowing dates } & \multicolumn{4}{|c|}{ Cereal units } & \multirow[b]{3}{*}{$\begin{array}{c}\text { Total cereal } \\
\text { units/fed. }\end{array}$} \\
\hline & \multicolumn{2}{|c|}{ Main products } & \multicolumn{2}{|c|}{ By products } & \\
\hline & $\begin{array}{c}\text { Root yield of } \\
\text { sugar beet }\end{array}$ & $\begin{array}{c}\text { wheat grain } \\
\text { yield }\end{array}$ & $\begin{array}{c}\text { Top yield of } \\
\text { sugar beet }\end{array}$ & $\begin{array}{c}\text { Straw yield } \\
\text { of wheat }\end{array}$ & \\
\hline D1 & 76.41 & 11.54 & 13.36 & 1.60 & 102.90 \\
\hline D2 & 81.14 & 12.62 & 14.64 & 1.66 & 110.05 \\
\hline D3 & 82.63 & 10.55 & 15.96 & 1.48 & 110.62 \\
\hline L.S.D. 5\% & 0.40 & 0.03 & 0.28 & 0.00 & 0.48 \\
\hline $\begin{array}{c}\text { pure stand of } \\
\text { sugar beet }\end{array}$ & 89.24 & - & 16.60 & - & 105.84 \\
\hline
\end{tabular}

D1 Sowing Wheat with Sugar.

D2 Sowing Wheat $1^{\text {st }}$ Irrigation.

D3 Sowing Wheat $2^{\text {nd }}$ Irrigation.

\section{Effect of wheat intercropping patterns} with sugar beet on cereal units.

Results in Table (12) indicated that the effect of intercropping patterns of wheat with sugar beet on cereal units were significantly in combined analysis. The differences were light compared with sugar beet pure stand. Intercropping pattern including $100 \%+25$ $\%$ sugar beet/wheat in ridges $60(\mathrm{~cm})$ wide $(\mathrm{S} 1)$ achieved the highest value for cereal units/fed (109.67 unit), intercropping pattern $100 \%+33.3 \%$ ridges S3 occupied the second ranked for both crop products of cereal units (108.02), followed by intercropping pattern including $(100 \%+25 \%)$ at terraces S2 107.54 cereal units/fed and the lowest value of total cereal unit was showed when wheat intercropped by $33.3 \%$ of its pure stand with sugar beet at terraces (106.20unit) S4. Results revealed that the intercropping patterns in ridges resulted cereal units more intercropping patterns at terraces. Total cereal units/fed were 103.62, 101.61, 102.05 and $100.35 \%$ of sugar beet pure stand(105.84). Badr (2013) mentioned that the highest values of cereal units/fed recorded at cropping system $(100 \%+25)$ sugar beet /wheat in both seasons and Hala Shehata (2015) found that (100\% sugar beet $+37.5 \%$ wheat ) gave the highest value than other intercropping patterns. 
Table (12): Effect of Intercropping patterns of wheat with sugar beet on total cereal units (root, top, grain, and straw yields/fed.) in combined analysis for (2013/2014 and 2014/2015) seasons.

\begin{tabular}{|c|c|c|c|c|c|}
\hline \multirow[b]{3}{*}{ Patterns } & \multicolumn{5}{|c|}{ Cereal units } \\
\hline & \multicolumn{2}{|c|}{ Main products } & \multicolumn{2}{|c|}{ By products } & \multirow[b]{2}{*}{$\begin{array}{c}\text { Total cereal } \\
\text { units/fed. }\end{array}$} \\
\hline & $\begin{array}{c}\text { Root yield of } \\
\text { sugar beet }\end{array}$ & $\begin{array}{c}\text { wheat grain } \\
\text { yield }\end{array}$ & $\begin{array}{c}\text { Top yield of } \\
\text { sugar beet }\end{array}$ & $\begin{array}{c}\text { Straw yield of } \\
\text { wheat }\end{array}$ & \\
\hline S1 & 82.46 & 10.46 & 15.39 & 1.37 & 109.67 \\
\hline $\mathbf{S 2}$ & 80.79 & 10.57 & 14.77 & 1.41 & 107.54 \\
\hline S3 & 79.22 & 12.58 & 14.48 & 1.75 & 108.02 \\
\hline S4 & 77.78 & 12.66 & 13.98 & 1.79 & 106.21 \\
\hline L.S.D. 5\% & 0.60 & 0.02 & 0.40 & 0.00 & 0.76 \\
\hline $\begin{array}{c}\text { pure stand of sugar } \\
\text { beet }\end{array}$ & 89.24 & - & 16.60 & - & 105.84 \\
\hline $\begin{array}{l}\text { S1 }(100 \% \text { Sugar }+25 \\
\text { S2 }(100 \% \text { Sugar }+25 \\
\text { S3 }(100 \% \text { Sugar }+33 . \\
\text { S4 }(100 \% \text { Sugar }+33\end{array}$ & $\begin{array}{l}\text { Wheat) ridges. } \\
\text { Wheat) beds. } \\
\text { Wheat) ridge } \\
\text { to Wheat) beds }\end{array}$ & & & & \\
\hline
\end{tabular}

3. Effect of nitrogen levels on cereal units:

Cereal units/fed was significantly affected by increasing nitrogen fertilizer levels from 80 to 100 up to $120 \mathrm{Kg} \mathrm{N} /$ fed as shown in Table (13). Results revealed that sugar beet pure stand gave the lowest value (105.84) compared with nitrogen fertilizer levels of 100 and $120 \mathrm{Kg} \mathrm{N} /$ fed for total cereal units/fed which were 109.13 and 108.90 cereal units/fed, respectively. Whereas, N. fertilizer level of $80 \mathrm{Kg} \mathrm{N} /$ fed showed the lowest value (102.9 unit) for cereal units/fed compared with nitrogen fertilizer levels of 100 or $120 \mathrm{Kg} \mathrm{N} /$ fed or sugar beet pure stand. The increases of total cereal units/fed for nitrogen fertilizer levels of 100 and $120 \mathrm{Kg} \mathrm{N} /$ fed were 3.10 and $2.89 \%$ respectively than cereal units/fed of sugar beet alone at $80 \mathrm{Kg} \mathrm{N} / \mathrm{fed}$ Mahrous et al. (1998) found that cereal units/fed had yield advantages by intercropping pattern $(100 \%$ wheat $+100 \%$ lentil $)$ under all rates of $\mathrm{N}$. fertilizer from 20 to $80 \mathrm{Kg} \mathrm{N} / \mathrm{fed}$ in both seasons.

Table (13): Effect of N. levels of wheat with sugar beet on total cereal units (root, top, grain, and straw yields/fed.) in combined analysis for $(2013 / 2014$ and $2014 / 2015)$ seasons.

\begin{tabular}{|c|c|c|c|c|c|}
\hline \multirow[b]{3}{*}{ N.levels } & \multicolumn{5}{|c|}{ Cereal units } \\
\hline & \multicolumn{2}{|c|}{ Main products } & \multicolumn{2}{|c|}{ By products } & \multirow[b]{2}{*}{$\begin{array}{c}\text { Total cereal } \\
\text { units/fed. }\end{array}$} \\
\hline & $\begin{array}{l}\text { Root yield of } \\
\text { sugar beet }\end{array}$ & $\begin{array}{c}\text { wheat grain } \\
\text { yield }\end{array}$ & $\begin{array}{l}\text { Top yield of } \\
\text { sugar beet }\end{array}$ & $\begin{array}{c}\text { Straw yield of } \\
\text { wheat }\end{array}$ & \\
\hline N1 & 78.58 & 11.49 & 13.90 & 1.57 & 105.55 \\
\hline $\mathbf{N 2}$ & 80.96 & 11.61 & 14.97 & 1.58 & 109.13 \\
\hline $\mathbf{N 3}$ & 80.64 & 11.60 & 15.09 & 1.59 & 108.90 \\
\hline L.S.D. 5\% & 0.55 & 0.03 & 0.31 & 0.00 & 0.62 \\
\hline $\begin{array}{c}\text { pure stand of } \\
\text { sugar beet }\end{array}$ & 89.24 & - & 16.60 & - & 105.84 \\
\hline
\end{tabular}

N1 $80 \mathrm{Kg} \mathrm{N} / \mathrm{fed}$.

$\mathrm{N} 2100 \mathrm{Kg} \mathrm{N} / \mathrm{fed}$.

N3 $120 \mathrm{Kg} \mathrm{N} /$ fed.

4. Effect of the interaction between sowing dates and intercropping patterns $(D \times S)$ on total cereal units /fed.

The interaction between sowing dates and intercropping patterns was significantly affected on total cereal units in combined analysis as shown in Table (14). Wheat planting with sugar beet at the first irrigation of sugar beet and growing wheat by $33.3 \%$ of its pure stand with sugar beet on ridges $(\mathrm{D} 2 \times \mathrm{S} 3$ ) produced the highest value (112.39) for total cereal units/fed whereas, wheat planting with sugar beet at sowing irrigation of sugar beet and growing wheat
$33.3 \%$ in beds showed the lowest value (100.50) (D1 $\times$ S4) for total cereal units/fed.

5. The interaction between sowing dates and nitrogen fertilizer levels on total cereal units/fed (D $\times \mathbf{N})$.

Data presented in Table (15) indicated that total cereal units/fed were significantly influenced by the interaction between sowing dates and nitrogen fertilizer levels in combined analysis. Data revealed that wheat planting before the second irrigation and fertilizer by $120 \mathrm{Kg} \mathrm{N} /$ fed gave the highest values (111.97) for cereal units $(\mathrm{D} 3 \times \mathrm{N} 3)$. Whereas, wheat 
planting with sugar beet at sugar beet sowing irrigation showed the lowest value (100.3) of cereal units/fed $(\mathrm{D} 1 \times \mathrm{N} 1)$. On the other hand, wheat planting at sugar beet sowing irrigation and fertilizer by 80,100 and $120 \mathrm{Kg} \mathrm{N} /$ fed gave lower values compared with sugar beet pure stand. These values were(100.3,
104.72, and 103.70) cereal units for these treatments, respectively. So, wheat planting with sugar beet at sowing irrigation of sugar beet under different nitrogen levels to obtain cereal units could not be recommended.

Table 14. Interaction effect between sowing dates and intercropping patterns of wheat with sugar beet on total cereal units (root, top, grain, and straw yields/fed.) in combined analysis for (2013/2014 and 2014/2015) seasons.

\begin{tabular}{|c|c|c|c|c|c|c|}
\hline \multirow{3}{*}{ 을 } & \multirow{3}{*}{ 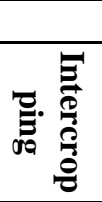 } & \multicolumn{5}{|c|}{ Cereal units } \\
\hline & & \multicolumn{2}{|c|}{ Main products } & \multicolumn{2}{|c|}{ By products } & \multirow{2}{*}{$\begin{array}{c}\text { Total cereal } \\
\text { units/fed. }\end{array}$} \\
\hline & & $\begin{array}{l}\text { Root yield of } \\
\text { sugar beet }\end{array}$ & $\begin{array}{l}\text { wheat grain } \\
\text { yield }\end{array}$ & $\begin{array}{l}\text { Top yield of } \\
\text { sugar beet }\end{array}$ & $\begin{array}{l}\text { Straw yield of } \\
\text { wheat }\end{array}$ & \\
\hline \multirow{5}{*}{ D1 } & S1 & 80.43 & 10.55 & 14.34 & 1.39 & 106.70 \\
\hline & $\mathbf{S 2}$ & 77.84 & 10.65 & 12.85 & 1.43 & 102.77 \\
\hline & S3 & 74.26 & 12.45 & 13.16 & 1.77 & 101.64 \\
\hline & S4 & 73.10 & 12.48 & 13.11 & 1.81 & 100.50 \\
\hline & S1 & 82.83 & 11.26 & 15.84 & 1.43 & 111.36 \\
\hline \multirow{3}{*}{ D2 } & $\mathbf{S 2}$ & 81.25 & 11.40 & 14.14 & 1.47 & 108.27 \\
\hline & S3 & 81.77 & 13.84 & 14.94 & 1.84 & 112.39 \\
\hline & S4 & 78.72 & 13.96 & 13.63 & 1.88 & 108.19 \\
\hline \multirow{4}{*}{ D3 } & S1 & 84.11 & 9.56 & 15.99 & 1.29 & 110.95 \\
\hline & $\mathbf{S 2}$ & 83.27 & 9.67 & 17.31 & 1.32 & 111.57 \\
\hline & S3 & 81.62 & 11.45 & 15.34 & 1.62 & 110.02 \\
\hline & S4 & 81.51 & 11.53 & 15.21 & 1.70 & 109.94 \\
\hline L.S. & D 5\% & 1.04 & 0.04 & 0.69 & 0.01 & 1.32 \\
\hline \multicolumn{2}{|c|}{$\begin{array}{l}\text { pure stand } \\
\text { of sugar } \\
\text { beet }\end{array}$} & 89.24 & - & 16.60 & - & 105.87 \\
\hline \multicolumn{4}{|c|}{$\begin{array}{l}\text { D1 Sowing Wheat with Sugar. } \\
\text { D2 Sowing Wheat } 1^{\text {st }} \text { Irrigation. } \\
\text { D3 Sowing Wheat } 2^{\text {nd }} \text { Irrigation. }\end{array}$} & \multicolumn{2}{|c|}{$\begin{array}{l}\text { S1 (100\% Sugar + 25\% Wheat) ridges. } \\
\text { S2 (100\% Sugar + 25\% Wheat) beds. } \\
\text { S3 (100\% Sugar }+33.3 \% \text { Wheat) ridges. } \\
\text { S4 (100\% Sugar }+33.3 \% \text { Wheat) beds. }\end{array}$} & \\
\hline
\end{tabular}

Table(15): Interaction effect between sowing dates and $\mathrm{N}$. levels of wheat with sugar beet on total cereal units (root, top, grain, and straw yields/fed.) in combined analysis for (2013/2014 and 2014/2015) seasons.

\begin{tabular}{|c|c|c|c|c|c|c|}
\hline \multirow[b]{3}{*}{ 章题 } & \multirow[b]{3}{*}{$\begin{array}{l}z \\
\frac{2}{2} \\
\frac{0}{2} \\
\infty\end{array}$} & \multicolumn{5}{|c|}{ Cereal units } \\
\hline & & \multicolumn{2}{|c|}{ Main products } & \multicolumn{2}{|c|}{ By products } & \multirow[b]{2}{*}{$\begin{array}{c}\text { Total cereal } \\
\text { units/fed. }\end{array}$} \\
\hline & & $\begin{array}{c}\text { Root yield } \\
\text { of sugar } \\
\text { beet }\end{array}$ & $\begin{array}{l}\text { wheat } \\
\text { grain yield }\end{array}$ & $\begin{array}{l}\text { Top yield } \\
\text { of sugar } \\
\text { beet }\end{array}$ & $\begin{array}{l}\text { Straw yield } \\
\text { of wheat }\end{array}$ & \\
\hline \multirow{4}{*}{ D1 } & N1 & 74.50 & 11.47 & 12.74 & 1.59 & 100.30 \\
\hline & $\mathbf{N} 2$ & 77.99 & 11.58 & 13.55 & 1.60 & 104.72 \\
\hline & $\mathbf{N 3}$ & 76.74 & 11.553 & 13.81 & 1.60 & 103.70 \\
\hline & $\mathbf{N} 1$ & 79.76 & 12.517 & 14.04 & 1.64 & 107.96 \\
\hline \multirow[t]{2}{*}{ D2 } & $\mathbf{N} 2$ & 81.83 & 12.686 & 14.98 & 1.66 & 111.16 \\
\hline & $\mathbf{N 3}$ & 81.84 & 12.648 & 14.90 & 1.66 & 111.05 \\
\hline \multirow{3}{*}{ D3 } & $\mathbf{N 1}$ & 81.49 & 10.49 & 14.94 & 1.47 & 108.39 \\
\hline & $\mathbf{N} 2$ & 83.07 & 10.577 & 16.38 & 1.49 & 111.52 \\
\hline & $\mathbf{N 3}$ & 83.33 & 10.59 & 16.56 & 1.49 & 111.97 \\
\hline L.S.D & $5 \%$ & 0.95 & N.S & N.S & N.S & 1.08 \\
\hline \multicolumn{2}{|c|}{ pure stand of sugar beet } & 89.24 & - & 16.60 & - & 105.87 \\
\hline \multicolumn{2}{|c|}{$\begin{array}{l}\text { D1 Sowing Wheat with Sugar. } \\
\text { D2 Sowing Wheat } 1^{\text {st }} \text { Irrigation. } \\
\text { D3 Sowing Wheat } 2^{\text {nd }} \text { Irrigation. }\end{array}$} & & $\begin{array}{l}\text { N1 } 80 \mathrm{Kg} \mathrm{N} / \mathrm{fed} \\
\text { N2 } 100 \mathrm{Kg} \mathrm{N} / \mathrm{fe} \\
\text { N3 } 120 \mathrm{Kg} \mathrm{N} / \mathrm{fe}\end{array}$ & & & \\
\hline
\end{tabular}


6. Effect of the interaction between intercropping patterns and $N$. fertilizer levels on $(S \times N)$ on total cereal units/fed.

Cereal units/fed of both sugar beet and wheat were significantly affected by the interaction between intercropping patterns and $\mathrm{N}$. fertilizer level $(\mathrm{S} \times \mathrm{N})$ in combined analysis as shown in Table (16). Results indicated that wheat intercropped by $25 \%$ of its pure stand in ridges $(60 \mathrm{~cm})$ width with sugar beet and fertilized at a rate of 100 and $120 \mathrm{Kg}$ N/fed $(\mathrm{S} 1 \times \mathrm{N} 2$ or N3) produced the highest value 110.50 and 110.99 , respectively without significant differences between them for cereal units/fed; simultaneously intercropping pattern including (sugar beet $100 \%+$ wheat $33.3 \%$ ) at terraces $120 \mathrm{~cm}$ wide at fertilizer by $80 \mathrm{Kg} \mathrm{N} /$ fed $(\mathrm{S} 4 \times \mathrm{N} 1)$ showed the lowest values (103.31) for cereal units/fed. for both crops. Similar results were obtained by Attia et al. (2007) and $\operatorname{Badr}(2013)$.

Table 16. Interaction effect between intercropping patterns and $\mathbf{N}$. levels of wheat with sugar beet on total cereal units (root, top, grain, and straw yields/fed.) in combined analysis for (2013/2014 and 2014/2015) seasons.

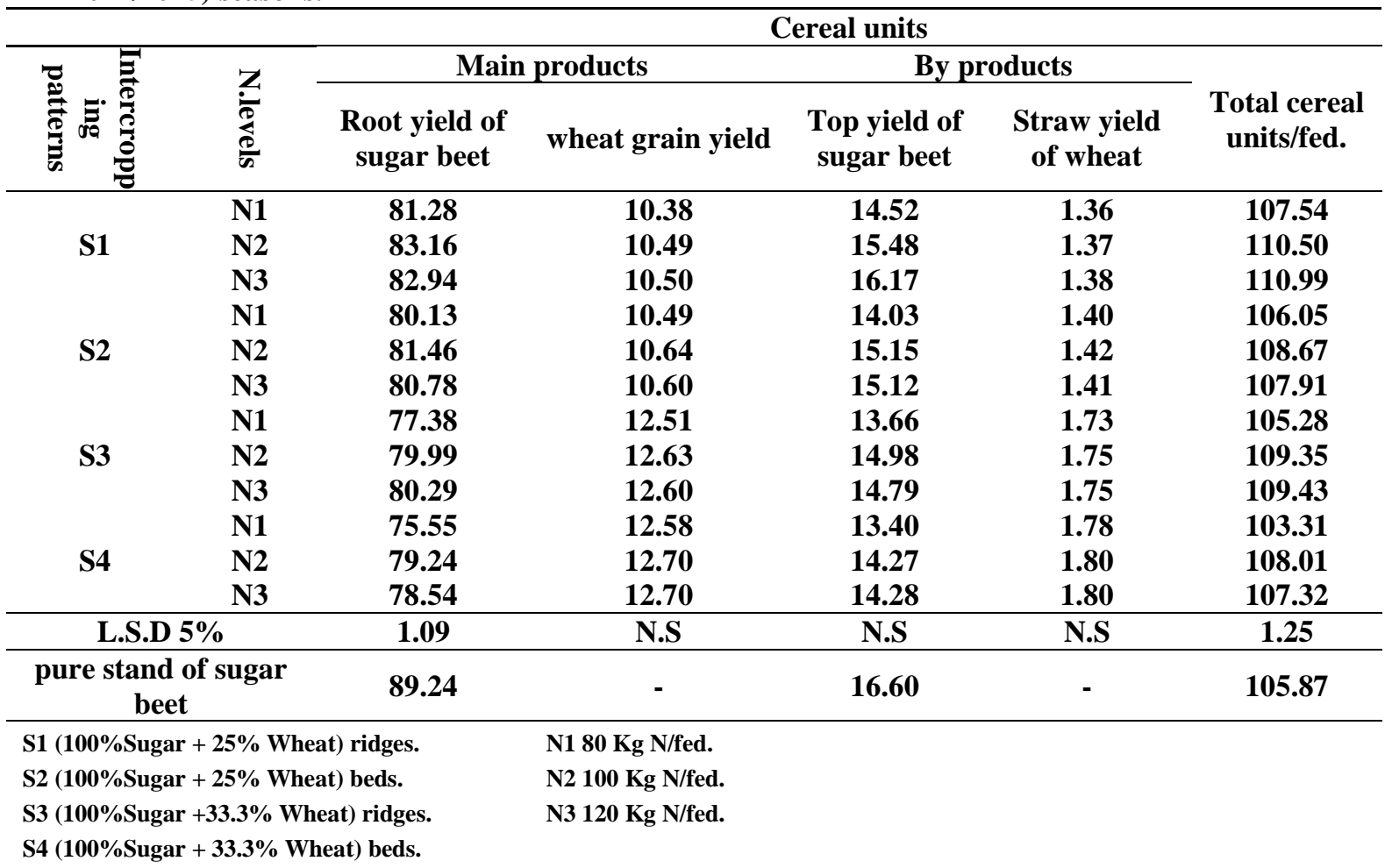

7. Effect of the interaction between wheat sowing dates, intercropping patterns and $\mathrm{N}$. fertilizer levels $(D \times S \times N)$ on total cereal units in combined.

Results presented in Table (17) illustrated that the interaction between three factors under study had a significant effect on cereal units/fed in combined analysis. The highest values of cereal units/fed (113.80) was obtained when wheat planting just before the first irrigation of sugar beet and intercropping patterns sugar beet $100 \%$ +wheat $33.3 \%$ (in ridges) and $120 \mathrm{Kg} \mathrm{N} / \mathrm{fed}(\mathrm{D} 2 \times \mathrm{S} 3 \times \mathrm{N} 3)$ whereas, the lowest value of cereal units/fed (97.76) was showed when wheat planting at sowing irrigation of sugar beet and (sugar beet $100 \%+33 \%$ wheat) at terraces intercropping pattern and $80 \mathrm{Kg} \mathrm{N} /$ fed (D1 $\times$ S4 $\times$ N1) Sanaa Saad (2007) found the highest values were (116.00 and 109.88 cereal units) recorded from intercropping faba bean with sugar beet in $1^{\text {st }}$ Dec. and faba bean density 70000 plant/fed and the highest fertilizer level $(100 \mathrm{Kg})$ compared to sugar beet pure stand (113.66 and 108 cereal units) in the first and second season, respectively when intercropping faba bean with sugar beet. 
Table 17. Interaction effect between wheat sowing dates, intercropping patterns and N. fertilizer levels of wheat with sugar beet on total cereal units (root, top, grain, and straw yields/fed.) in combined analysis for $(2013 / 2014$ and $2014 / 2015)$ seasons.

\begin{tabular}{|c|c|c|c|c|c|c|c|}
\hline \multirow[b]{3}{*}{$\begin{array}{c}\text { Sowing } \\
\text { dates }\end{array}$} & \multirow[b]{3}{*}{$\begin{array}{c}\text { Intercropping } \\
\text { patterns }\end{array}$} & \multirow[b]{3}{*}{$\begin{array}{c}\text { N. } \\
\text { Levels }\end{array}$} & \multicolumn{5}{|c|}{ Cereal units } \\
\hline & & & \multicolumn{2}{|c|}{ Main products } & \multicolumn{2}{|c|}{ By products } & \multirow[b]{2}{*}{$\begin{array}{c}\text { Total } \\
\text { cereal } \\
\text { units/fed. }\end{array}$} \\
\hline & & & $\begin{array}{l}\text { Root yield } \\
\text { of sugar } \\
\text { beet }\end{array}$ & $\begin{array}{c}\text { wheat } \\
\text { grain yield }\end{array}$ & $\begin{array}{c}\text { Top } \\
\text { yield of } \\
\text { sugar } \\
\text { beet }\end{array}$ & $\begin{array}{c}\text { Straw } \\
\text { yield of } \\
\text { wheat }\end{array}$ & \\
\hline \multirow{13}{*}{ D1 } & \multirow{3}{*}{ S1 } & N1 & 78.80 & 10.49 & 13.41 & 1.38 & 104.08 \\
\hline & & $\mathbf{N 2}$ & 81.75 & 10.62 & 14.01 & 1.39 & 107.77 \\
\hline & & $\mathbf{N 3}$ & 80.72 & 10.53 & 15.60 & 1.39 & 108.24 \\
\hline & \multirow{3}{*}{$\mathbf{S 2}$} & N1 & 77.09 & 10.58 & 12.06 & 1.42 & 101.15 \\
\hline & & $\mathbf{N 2}$ & 77.76 & 10.70 & 13.56 & 1.44 & 103.46 \\
\hline & & $\mathbf{N 3}$ & 78.69 & 10.67 & 12.92 & 1.44 & 103.72 \\
\hline & \multirow{4}{*}{$\mathbf{S 3}$} & N1 & 71.43 & 12.39 & 12.62 & 1.76 & 98.20 \\
\hline & & $\mathbf{N 2}$ & 77.03 & 12.50 & 13.42 & 1.78 & 104.73 \\
\hline & & $\mathbf{N 3}$ & 74.34 & 12.46 & 13.44 & 1.78 & 102.02 \\
\hline & & N1 & 70.68 & 12.42 & 12.86 & 1.80 & 97.76 \\
\hline & \multirow[t]{3}{*}{ S4 } & $\mathbf{N 2}$ & 75.42 & 12.50 & 13.19 & 1.81 & 102.93 \\
\hline & & $\mathbf{N 3}$ & 73.20 & 12.53 & 13.28 & 1.82 & 100.83 \\
\hline & & N1 & 82.06 & 11.15 & 15.35 & 1.42 & 109.99 \\
\hline \multirow{10}{*}{ D2 } & \multirow[t]{3}{*}{ S1 } & $\mathbf{N 2}$ & 82.98 & 11.30 & 15.55 & 1.43 & 111.26 \\
\hline & & $\mathbf{N 3}$ & 83.46 & 11.33 & 16.62 & 1.44 & 112.85 \\
\hline & & N1 & 79.89 & 11.29 & 13.74 & 1.46 & 106.39 \\
\hline & \multirow[t]{2}{*}{$\mathbf{S 2}$} & $\mathbf{N 2}$ & 81.95 & 11.52 & 14.27 & 1.49 & 109.23 \\
\hline & & N3 & 81.91 & 11.39 & 14.42 & 1.48 & 109.20 \\
\hline & \multirow{4}{*}{ S3 } & N1 & 80.53 & 13.74 & 14.01 & 1.83 & 110.11 \\
\hline & & $\mathbf{N} 2$ & 81.86 & 13.92 & 15.65 & 1.85 & 113.28 \\
\hline & & $\mathbf{N 3}$ & 82.93 & 13.87 & 15.15 & 1.85 & 113.80 \\
\hline & & N1 & 76.56 & 13.88 & 13.07 & 1.87 & 105.38 \\
\hline & \multirow[t]{3}{*}{ S4 } & $\mathbf{N 2}$ & 80.53 & 14.01 & 14.44 & 1.88 & 110.86 \\
\hline \multirow{13}{*}{ D3 } & & N3 & 79.06 & 14.00 & 13.39 & 1.89 & 108.34 \\
\hline & & N1 & 82.97 & 9.51 & 14.79 & 1.28 & 108.56 \\
\hline & \multirow[t]{3}{*}{ S1 } & $\mathbf{N} 2$ & 84.74 & 9.56 & 16.88 & 1.29 & 112.47 \\
\hline & & $\mathbf{N 3}$ & 84.64 & 9.61 & 16.28 & 1.30 & 111.83 \\
\hline & & N1 & 83.42 & 9.60 & 16.30 & 1.31 & 110.63 \\
\hline & \multirow[t]{2}{*}{ S2 } & $\mathbf{N 2}$ & 84.67 & 9.69 & 17.61 & 1.32 & 113.29 \\
\hline & & $\mathbf{N 3}$ & 81.73 & 9.73 & 18.02 & 1.32 & 110.80 \\
\hline & \multirow{4}{*}{ S3 } & N1 & 80.18 & 11.40 & 14.37 & 1.61 & 107.56 \\
\hline & & $\mathbf{N} 2$ & 81.09 & 11.47 & 15.88 & 1.62 & 110.06 \\
\hline & & $\mathbf{N 3}$ & 83.60 & 11.47 & 15.77 & 1.63 & 112.47 \\
\hline & & N1 & 79.40 & 11.45 & 14.29 & 1.68 & 106.82 \\
\hline & \multirow[t]{2}{*}{ S4 } & $\mathbf{N 2}$ & 81.77 & 11.58 & 15.17 & 1.70 & 110.22 \\
\hline & & $\mathbf{N 3}$ & 83.36 & 11.56 & 16.17 & 1.70 & 112.79 \\
\hline L.S.D & $5 \%$ & - & 1.90 & - & - & - & 2.16 \\
\hline \multicolumn{2}{|c|}{ pure stand of sugar beet } & - & 89.24 & - & 16.60 & - & 105.87 \\
\hline
\end{tabular}

D1 Sowing Wheat with Sugar. $\quad$ S1 (100\%Sugar + 25\% Wheat) ridges. $\quad$ N1 $80 \mathrm{Kg} \mathrm{N} / \mathrm{fed}$.

D2 Sowing Wheat $1^{\text {st }}$ Irrigation. S2 (100\%Sugar $+25 \%$ Wheat) beds. $\quad$ N2 $100 \mathrm{Kg} \mathrm{N} / \mathrm{fed}$.

D3 Sowing Wheat $2^{\text {nd }}$ Irrigation. S3 (100\%Sugar $+33.3 \%$ Wheat) ridges. $\quad \mathrm{N} 3120 \mathrm{Kg} \mathrm{N} / \mathrm{fed}$.

S4 (100\% Sugar $+33.3 \%$ Wheat) beds. 
Table 18. Interaction effect between wheat sowing dates, intercropping patterns and N. fertilizer levels of wheat with sugar beet on top and root yields (ton/fed) of sugar beet and straw and grain yields(ton/fed) of wheat at harvesting in combined analysis for (2013/2014 and 2014/2015) seasons.

\begin{tabular}{|c|c|c|c|c|c|c|}
\hline \multirow[b]{2}{*}{$\begin{array}{l}\text { Sowing } \\
\text { dates }\end{array}$} & \multirow[b]{2}{*}{$\begin{array}{c}\text { Intercropping } \\
\text { patterns }\end{array}$} & \multirow[b]{2}{*}{ N.levels } & \multicolumn{2}{|c|}{ sugar beet } & \multicolumn{2}{|c|}{ wheat } \\
\hline & & & $\begin{array}{c}\text { Top yield } \\
\text { (ton/fed) }\end{array}$ & $\begin{array}{c}\text { Root yield } \\
\text { (ton/fed) }\end{array}$ & $\begin{array}{c}\text { Straw yield } \\
\text { (ton/ fed) }\end{array}$ & $\begin{array}{c}\text { Grain } \\
\text { yield(ton/ fed) }\end{array}$ \\
\hline \multirow{13}{*}{ D1 } & \multirow{3}{*}{ S1 } & N1 & 13.408 & 31.522 & 1.377 & 1.048 \\
\hline & & N2 & 14.012 & 32.702 & 1.390 & 1.062 \\
\hline & & N3 & 15.595 & 32.292 & 1.390 & 1.055 \\
\hline & \multirow{3}{*}{$\mathbf{S 2}$} & N1 & 12.060 & $\mathbf{3 0 . 8 3 7}$ & 1.423 & 1.058 \\
\hline & & N2 & 13.561 & 31.103 & 1.439 & 1.070 \\
\hline & & N3 & 12.915 & 31.477 & 1.435 & 1.067 \\
\hline & \multirow{3}{*}{ S3 } & N1 & 12.619 & 28.572 & 1.763 & 1.239 \\
\hline & & $\mathbf{N} 2$ & 13.422 & 30.812 & 1.776 & 1.250 \\
\hline & & N3 & 13.436 & 29.735 & 1.776 & 1.246 \\
\hline & \multirow{3}{*}{ S4 } & N1 & 12.855 & 28.273 & 1.798 & 1.242 \\
\hline & & N2 & 13.190 & 30.170 & 1.807 & 1.250 \\
\hline & & N3 & 13.276 & 29.282 & 1.816 & 1.253 \\
\hline & \multirow{3}{*}{ S1 } & N1 & 15.345 & 32.825 & 1.416 & 1.115 \\
\hline \multirow{10}{*}{ D2 } & & N2 & 15.550 & 33.193 & 1.433 & 1.129 \\
\hline & & N3 & 16.616 & 33.383 & 1.442 & 1.133 \\
\hline & \multirow{3}{*}{ S2 } & N1 & 13.742 & 31.958 & 1.460 & 1.129 \\
\hline & & N2 & 14.267 & 32.780 & 1.487 & 1.152 \\
\hline & & N3 & 14.423 & 32.765 & 1.476 & 1.139 \\
\hline & \multirow{3}{*}{ S3 } & N1 & 14.004 & 32.210 & 1.828 & 1.374 \\
\hline & & N2 & 15.652 & 32.748 & 1.852 & 1.392 \\
\hline & & N3 & 15.150 & 33.170 & 1.845 & 1.387 \\
\hline & \multirow{3}{*}{ S4 } & N1 & 13.068 & 30.625 & 1.867 & 1.388 \\
\hline & & N2 & 14.438 & 32.210 & 1.884 & 1.401 \\
\hline \multirow{13}{*}{ D3 } & & N3 & 13.393 & 31.625 & 1.887 & 1.400 \\
\hline & \multirow{3}{*}{ S1 } & N1 & 14.792 & 33.183 & 1.283 & 0.951 \\
\hline & & N2 & 16.878 & 33.893 & 1.292 & 0.956 \\
\hline & & N3 & 16.282 & 33.850 & 1.297 & 0.961 \\
\hline & \multirow{3}{*}{ S2 } & N1 & 16.298 & 33.363 & 1.307 & 0.960 \\
\hline & & N2 & 17.609 & 33.865 & 1.320 & 0.969 \\
\hline & & $\mathbf{N 3}$ & 18.017 & 32.690 & 1.326 & 0.973 \\
\hline & \multirow{3}{*}{ S3 } & N1 & 14.371 & 32.070 & 1.613 & 1.140 \\
\hline & & N2 & 15.876 & 32.432 & 1.621 & 1.147 \\
\hline & & N3 & 15.770 & 33.437 & 1.624 & 1.146 \\
\hline & \multirow{3}{*}{ S4 } & N1 & 14.288 & 31.757 & 1.685 & 1.145 \\
\hline & & N2 & 15.170 & 32.705 & 1.703 & 1.158 \\
\hline & & N3 & 16.170 & 33.340 & 1.702 & 1.156 \\
\hline & L.S.D 5\% & & N.S & 0.758 & N.S & N.S \\
\hline & Pure Stand & & 16.599 & 35.696 & 4.871 & 3.248 \\
\hline \multicolumn{2}{|c|}{ D1 Sowing Wheat with Sugar. } & & \multicolumn{2}{|c|}{ S1 $(100 \%$ Sugar $+25 \%$ Wheat $)$ ridges. } & & N1 $80 \mathrm{Kg} \mathrm{N} / \mathrm{fed}$ \\
\hline \multicolumn{2}{|c|}{ D2 Sowing Wheat $1^{\text {st }}$ Irrigation. } & & \multicolumn{2}{|c|}{ S2 (100\%Sugar $+25 \%$ Wheat) beds. } & & N2 $100 \mathrm{Kg} \mathrm{N/fed.}$ \\
\hline D3 Sowing & Wheat $2^{\text {nd }}$ Irrigation. & & S3 (100\%Sugar - & Wheat) ridges. & & N3 120 Kg N/fed. \\
\hline & & & S4 (100\%Sugar - & Wheat) beds. & & \\
\hline
\end{tabular}




\section{References}

Abd El-Gwad, M. S. A; Abd El-Aziz T. K. and Abd El-Galil M. A. (2008). Effect of intercropping wheat with fodder beet under different levels of Napplication on yield and quality. Annals Agric. Sci., Ain Shams Univ., Cairo, 53 (2): 353-362.

Abd El-Zaher, Sh. R; Osman M. S. H. and Sherif, Sahar. A. (2009). Effect of intercropping barley with sugar beet under different nitrogen fertilization levels on yield and yield components. Egypt. J. of Appl. Sci., 24 (6B): 531-550.

Abou-Elela, A. M. (2012). Effect of intercropping system and sowing dates of wheat intercropped with sugar beet. J. Plant Production, Mansoura Univ., 3 (12): 3101-3116.

Attia, A. N. E; Said E. M; Ghanima M.H. and Ibrahim M. E. M. (2007). Impact of nitrogen levels on growth and yield of sugar beet intercropped with faba bean and wheat. J. Agric. Sci.

Badr, K. S. K. A. (2013). Effect of intercropping wheat with sugar beet under different nitrogen fertilizer levels. M.Sc. Thesis, Fac. Agric., Moshtohr, Benha Univ., Egypt.

Brockhaus, F.A. (1962) ABC der Landwirtschaft, Vol.I VEB, F.A. BrockhausVerlag, Leipzig.G.D.R.pp 790 (in German).

De Wit, C. T. (1960). Intercropping its importance and research needs. Part 1. Competition and yield advantages. Verslag Landbov Wkundige Onderz.,66: 1-82. [C.A. Willey, R. W., 1979 (Field Crop Abst., 32: 1-10)].

Dina El-Sherief (2013). Effect of intercropping faba bean and wheat on sugar beet yield and its components. M.Sc. Thesis, Fac. Agric., Kafer Elsheikh Univ., Egypt.

Gomez, K.A. and Gomez A.A. (1984). Statiscal Procedures for Agricultural Research.2nd, (ed.).John Wiley and Sons, New York, U.S.A.
Shehata, Hala. H(2015). Sowing sugar beet with wheat cultivars under different intercropping patterns. M. Sci., Thesis Fac. Of Agric., Minia Univ., Egypt.

Ibrahim, E. M; Badr M. M. A. and Abd El-Zaher Sh. R. (2008). Response of some intercropping systems of wheat with sugar beet to bio-mineral nitrogenous fertilization. Proceeding (The second field crop conference) FCRI, ARC, Giza, Egypt: 435-451.

Mahrous, M. A; Eisa M. S. and Abd - Alla A. A. (1998). Effect of intercropping wheat with lentil at varying nitrogen fertilizations rates on yield and their components. Ann. of Agric. Sc., Moshtohor, 36 (1): 61-69.

Mc. Gillchrist, C. A. (1965). Analysis of competition experiments. Biometrics, 21:975-985.

Metwally, I. O. E; Bassal S. A. A.; Gabr E. M. A. and Abd El-All A. M. (1997). Effect of potassium fertilizer levels on productivity of intercropped fodder beet and faba bean. J. Agric. Sci. Mansoura Univ., 22 (1): 23-31.

MSTATC - C, (1990).A Microcomputer program for Design Management and Analysis of Agronomic Research Experiments Michigan State Univ.

Sanaa Saad S.H. (2007). Effect of intercropping and nitrogenous fertilization on growth and yield of sugar beet. Ph. D. Thesis, Fac. of Agric., Moshtohor (Benha Univ.) Egypt.

Toaima, S. E. A. (2006). Response of onion, faba bean and wheat to intercropping with fodder beet under different fertilizer levels of NPK. Minufiya J. Agric.Res., 31 (4): 939-956.

Waller, R.A. and Duncan D.B. (1969) Abays rule for symmetric multiple comparison problem. Amer. Stat. Assoc. J., 1485-1503.

Willey, R. W. (1979). Intercropping- Its importance and research needs. Part 1: Competition and yield advantages.(C. F. Field Crop Abst., 32 (1): 1-10). 


\section{الإدارة المحصوليه المتكامله من خلال الميعاد الامثل للزراعه ومستويات التسميد النتروجينى فى تحميل القمح مع بنجر السكر. • • العلاقات التنافسيه والميزه المحصوليه.

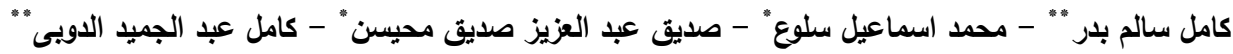 "كلية الزراعه بمشتهر جامعة بنها "* معهد بحوث المحاصيل الحقليه مركز البحوث الزراعيه.}

أجريت تجربتان حقليان فى موسمى الزراعه 2014/2013 , 2015/2014 فى محطة البحوث الزراعيه بسرس الليان محافظة المنوفيه - مركز البحوث الزراعيه وذللك لدراسة تاثير ثلاث مواعيد لزراعة القمح مع بنجر السكر واربع نظم لتحميل القمح مع بنجر السكر تحت مستويات مختلفه من التسميد النيتروجينى على العلاقات التتافسيه والميزه المحصوليه ووحدات الحبوب لمحصولى بنجر السكر والقمح وكان التصميم المستخدم قطع منشقة مرنين فى ثنلاث مكررات. وكانت اهم النتائج المتحصل عليها هـى:1. زاد معدل مكافىء استغلال الارض عن الواحد الصحيح نتيجة للتحميل وتاثر هذا المعدل بمواعيد زراعة القمح ونظم الزراعة والتسميد النيتروجينى. وكانت أعلى القيم لمكافىء استغلال الأرض (1.36) وتم الحصول عليه من زراعة القمح مع بنجر السكر فى الريه الاولى للبنجر (رية المحاياه) ونظم الزراعه 100\% بنجر سكر +33.3\% قمح بالزراعه على خطوط (60 سم) ومعدل النسميد النتروجينى 120 كيلو نتروجين /فدان فى التحليل المشترك لكلا الموسمين 2014/2013 , 2015/2014.

2. اثر معامل الحثد النسبى بمواعيد زراعة القمح مع البنجر ونظم الزراعه والتسميد النتروجينى وكانت افضل القيم لمعامل الحشد النسبى

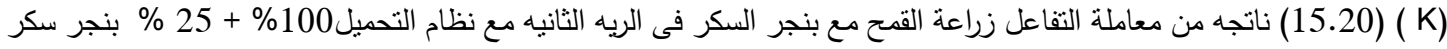
مع القمح فى خطوط (60سم) والتسميد بمعدل 100 كجم نتروجين للفدان (D2 × S1 × N2) فى التحليل المشترك للموسمين. 3. كانت قيم العدوانية فى التحليل المشترك لبنجر السكر سالبه (مسود) والقحح موجب (سائد). وكانت اقل القيم للعدوانيه (0.17) بزراعة القمح مع الريه الثانيه للبنجر مع نظام الزراعة (100\% بنجر سكر + 33.3\% قمح) على خطوط ومعدل التسميد النتروجينى 12 كجم نيتروجين/فدان (D3 × S3 × N3).

4. زادت وحدات الحبوب الناتجه من وحدة المساحه نتيجة التحميل ولقد تحققت اعلى القيم لوحدات الحبوب حيث كانت (113.80) وحده/فدان فى التحليل المشترك للموسمين ناتجة من زراعة القمح مع بنجر السكر عند الرية الاولى للبنجر ونظام التحميل (100\% بنجر

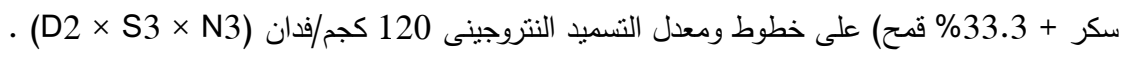
ومن الدراسة نستتج انه للحصول على افضل النتائج لعلاقلات التناقس والميزه المحصولية ووحدات الحبوب زراعة القمح مع الريةالاولى لبنجر السكر (رية المحاياة) ومع نظام التحميل (100\% بنجر سكر + 33.3 \% قمح) على خطوط مع إضافة 100 او 120 كجم نتروجين/فدان تحت ظروف التجربه. 